\title{
A Three- dimensional Model of Ethical Competencies' Education in Accounting Program
}

\author{
Jafar Babajani* \\ Full Professor of Accounting Faculty, Allame Tabatabai University, Tehran, Iran \\ (Corresponding Author) \\ Jafar.babajani@gmail.com \\ Ali saghafi \\ Full Professor of Accounting Faculty, Allame Tabatabai University, Tehran, Iran \\ (Iranianaa@yahoo.com) \\ Hiva Rastegar Moghadam \\ Ph.D. Candidate of Accounting, Allame Tabatabai University, Tehran, Iran. \\ (Hivarmm@gmail.com)
}

\begin{abstract}
:
One of the leading characteristics of accounting profession is its accountability to the public. Unfortunately, occurrence of recent financial crisis has dwindled the trust to accounting profession. Many researchers believe that the destroyed trust can only be recovered by ethical leadership and learning ethics. Therefore, the objective of the present research is to offer a model for ethical competencies' education in accounting profession. The desired model includes three aspects namely recognition of ethical competencies, teaching method, and the accounting course in which the mentioned competencies should be taught. In this research, the required data were gathered in 1398(Iranian year) from the 150 questionnaires which were distributed among accounting elites including accounting lecturers and certified public accountants. Fuzzy Delphi methodology with screening approach is used to analyze the data. Based on the results, eleven ethical competencies are recognized which should be taught using combinational method separately rather than teaching as a sub-set of an accounting course. In general, it is expected that using the mentioned model for ethical competencies' education in academic environments will familiarize the accounting students with the necessary competencies needed to make ethical decisions. And then, by improving the accounting decision making in workplaces, graduates can pave the way toward public's trust to accounting profession.
\end{abstract}

Keywords: Three-dimensional model of ethical competencies' education, Ethical competencies, Teaching Method, Teaching Course, Fuzzy Delphi methodology.

\section{Copyrights (C) (1)(2)}

This license only allowing others to download your works and share them with others as long as they credit you, but they can't change them in any way or use them commercial. 


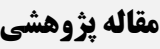

دو فصلنامه حسابدارى ارزشى و رفتارى- سال ينجم، شماره دهم، ياييز و زمستان 99 |، صفحه ا-1

\section{مدل سه بعدى آموزش صلاحيت هاى اخلاقى در رشته حسابدارى

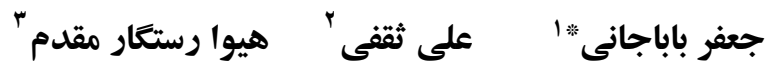

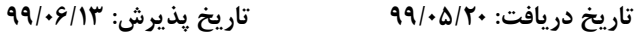

جكيده

يكى از ويزگى -هاى اصلى حرفه حسابدارى، بذيرش مسئوليت پاسخكَويى نسبت به عموم

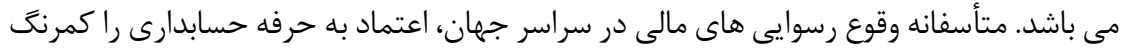

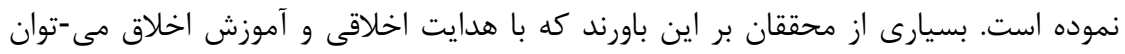

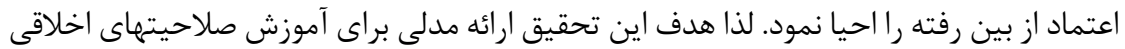

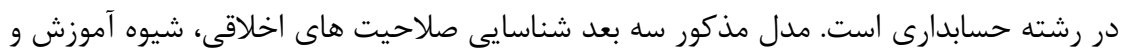

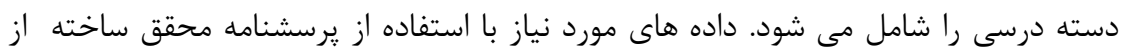
•ها نفر از خبركان غربال شده شامل استادان حسابدارى و حسابداران رسمى ايران در سال سال

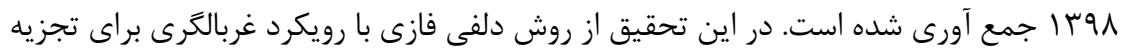
و تحليل داده ها استفاده شده است.

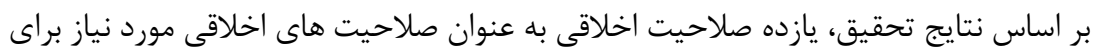

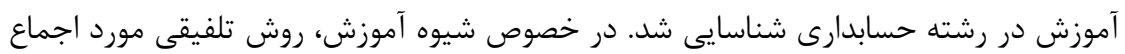

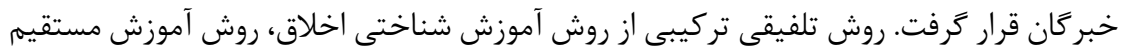

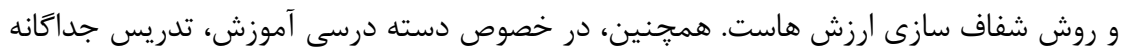

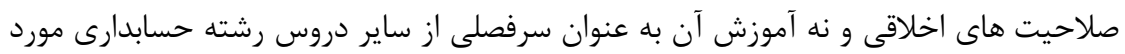

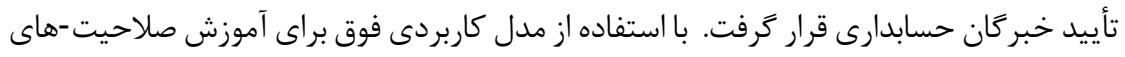

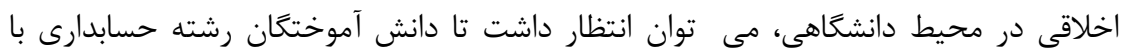

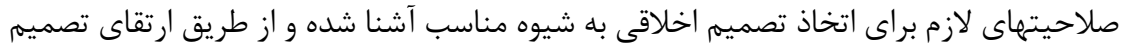

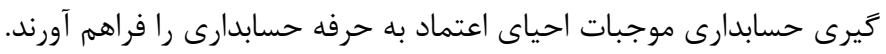
كليد وازه ها: مدل سه بعدى آموزش صلاحيت هاى اخلاقى، صلاحيت هاى اخلاقى، شيوه

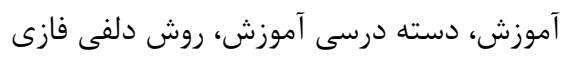

'استاد گروه حسابدارى دانشكاه علامه طباطبائى، تهران، ايران( نويسنده مسئول)، Jafar.babajani@gmail.com "استاد تروه حسابدارى دانشخاه علامه طباطبائى، تهران، ايران (Iranianaa@yahoo.com)

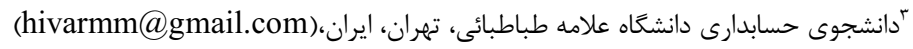




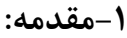

در دنياى تجارى امروز، موضوعاتى نظير حداكثر كردن سود، فشارهاى رقابتى و رشد سريع

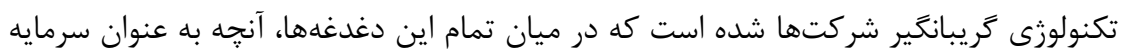

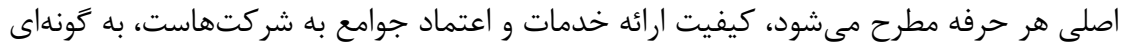

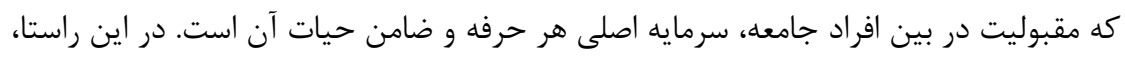

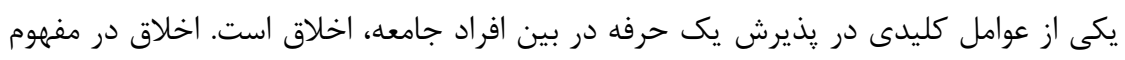

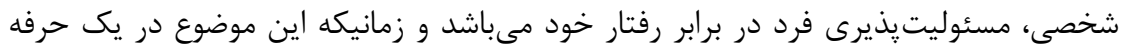
مطرح مىشود، شامل مسئوليت صد IrV

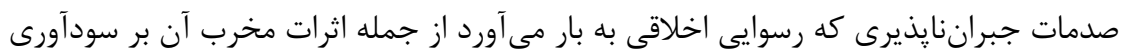
شركت، بر هيجكس يوشيده نيست.

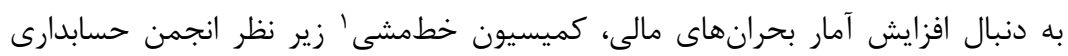

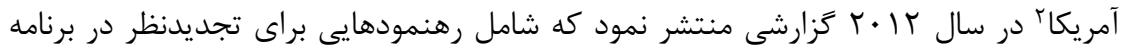

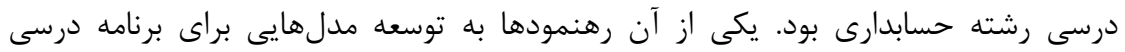

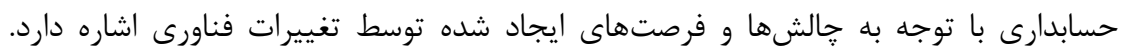

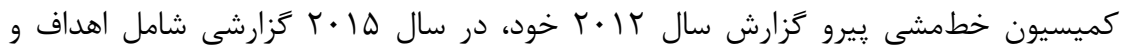

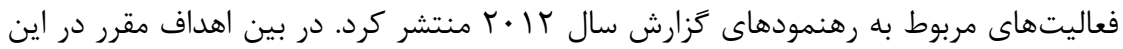

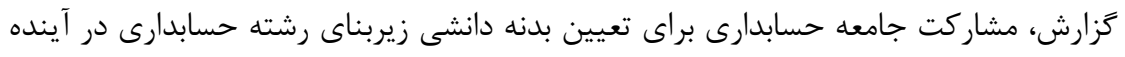

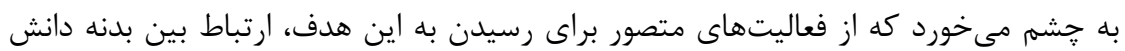

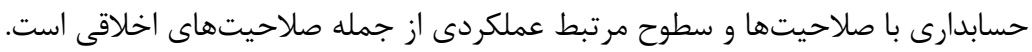

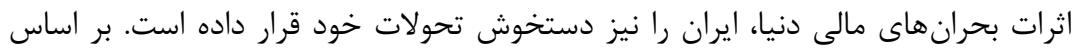

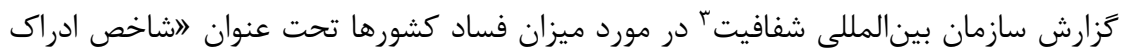

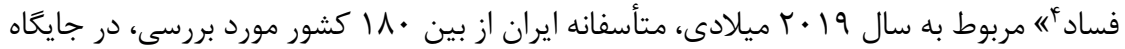

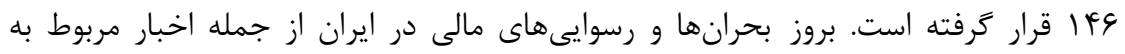

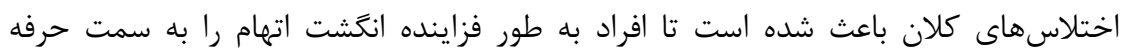

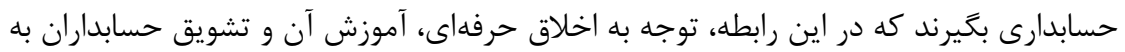

1 Pathways Commission

2 American Accounting Association (AAA)

${ }^{3}$ Transparency International

${ }^{4}$ Corruption Perceptions Index 


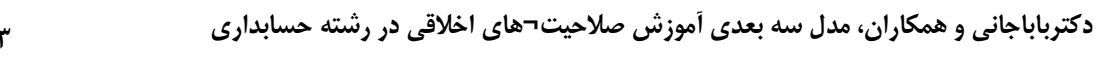

اعمال قضاوت حرفهاى به جاى قضاوت شخصى مسيرى است كه مىتواند اعتماد به حسابدارى را احيا كند.

در محيط دانشخاهى ايران، جايى كه لازم است بيش از هر محفلى به رابطه ديرين اخلاق و

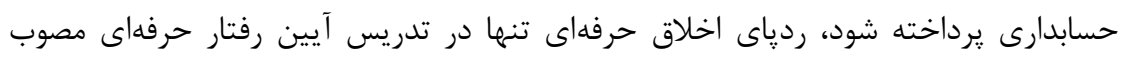

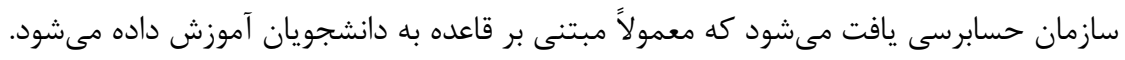

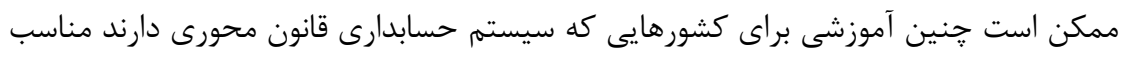
باشد، اما آموزش اخلاق در اين سطح براى كشورهايى از جمله ايران كه به سمت استانداردهاى بين المللى گزارشخرى مالى حركت كردهاند، كافى نيست. استانداردهاى يادشده اصول

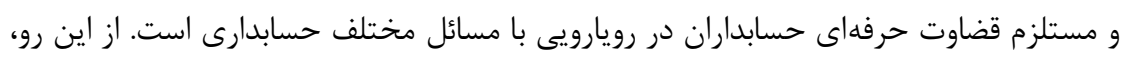
دانشجويان رشته حسابدارى بايد به صلاحيتهايى مجهز شوند تا امكان انتخاب و تميز دادن اين قضاوتها از قضاوتهاى شخصى براى ايشان فراهم گردد. متأسفانه آموزشهايى كه بتواند دانش -

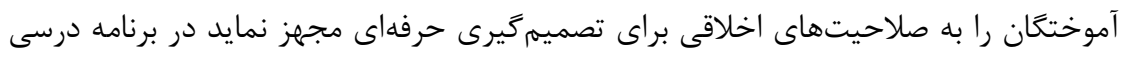

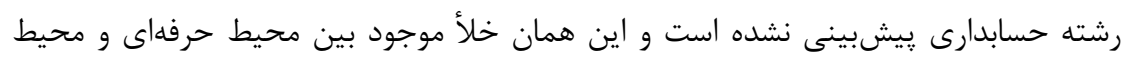

$$
\text { دانشعاهى رشته حسابدارى است. }
$$

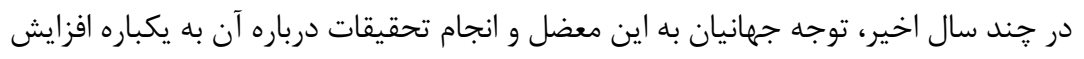

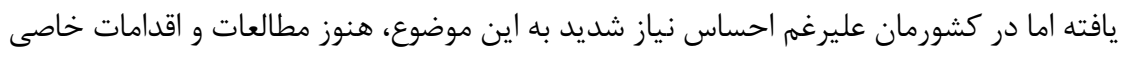

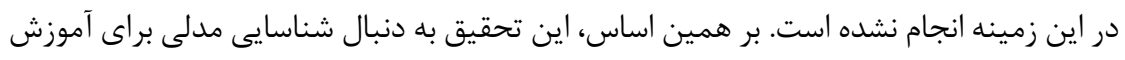

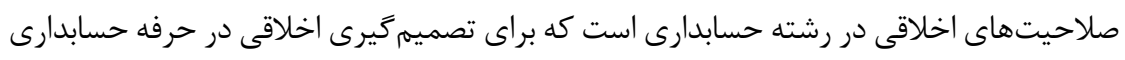
ضرورى است و بايد در سرفصل دروس رشته حسابدارى كنجانده شود تا از اين طريق بتوان

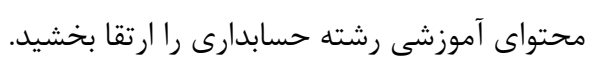

\section{r-مبانى نظرى و ييشينه يزوهش}

امروزه اخلاق موضوعى است كه توجه زيادى را در سراسر جامعه ما به خود معطوف كرده است، دليل اين توجه دو نشانه بارز است: اول نقش مهمم و يرمعناى رفتار اخلاقى در حفظ و بقاى رونى

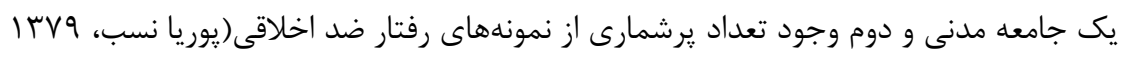

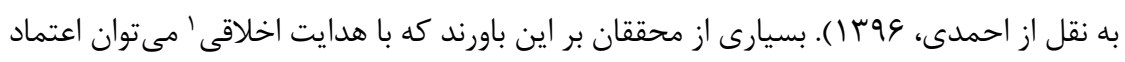

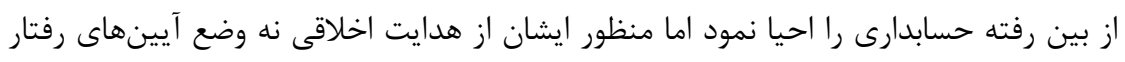
حرفهاى است جراكه قبل از وقوع رسوايىها و معضلات مالى، آيينهاى مدون رفتار حرفهاى در

\footnotetext{
${ }^{1}$ Ethical Guidance
} 
سراسر دنيا در انجمنهاى حرفهاى موجود بوده، بلكه منظور اصلى ايشان از هدايت اخلاقى، درى

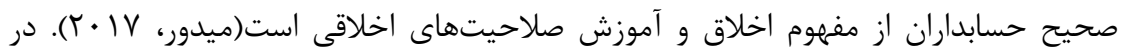

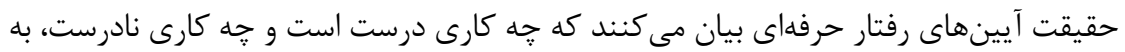

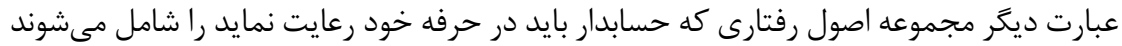

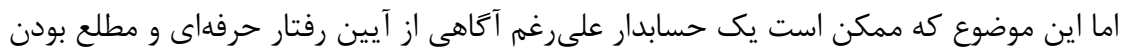

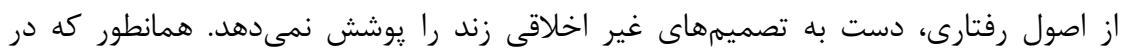
رسوايىهاى اخلاقى سالهاى اخير، اغلب متهمان از آيين رفتار حرفهاى مطلع بوده و آكاهانه

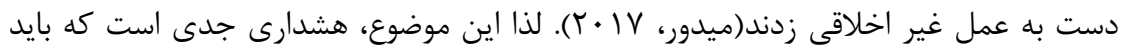

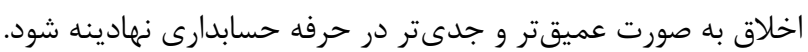

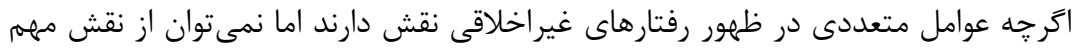

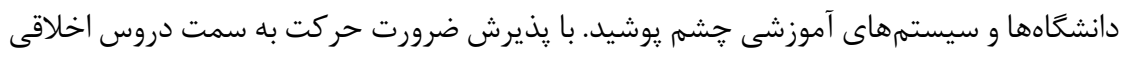

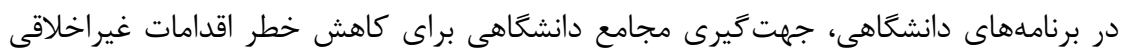

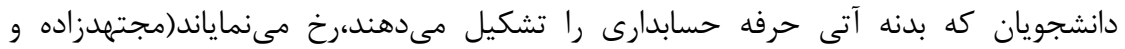

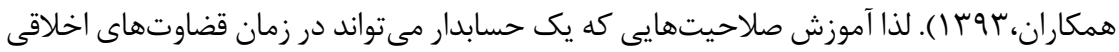
مجهز باشد، مى تواند در اين ميان رهگشا باشد. مدل آموزش مورد بررسى در تحقيق حاضر داراى سه بعد شامل شناسيايى رهائ صلاحيتهاى

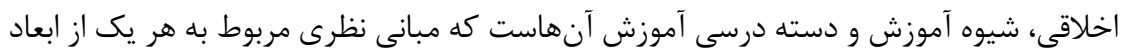

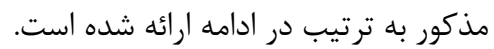

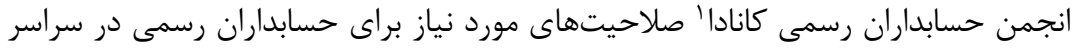

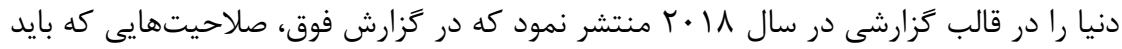

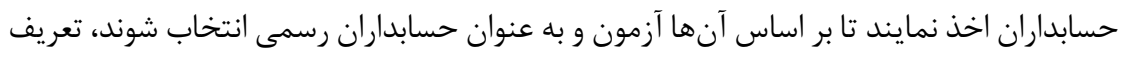

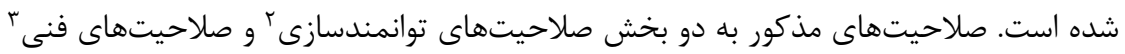

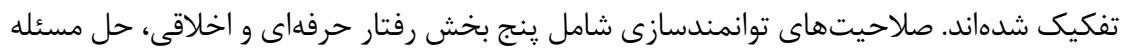

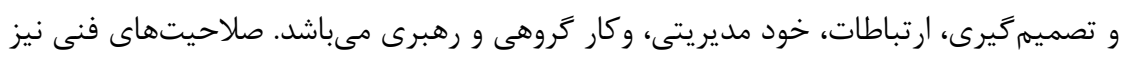

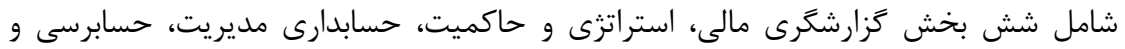

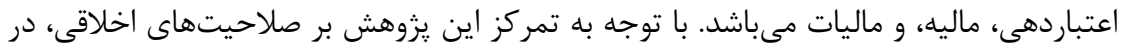

${ }^{1}$ Chartered Professional Accountants Canada ${ }^{2}$ Enabling Competencies

${ }^{3}$ Technical Competencies 
ادامه تنها به بررسى صلاحيتهاى زيرمجموعه بخش "رفتار حرفهاى و اخلاقى" از مجموعه صلاحيتهاى توانمندسازى مى يردازيم.

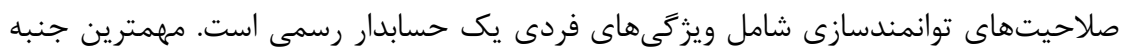

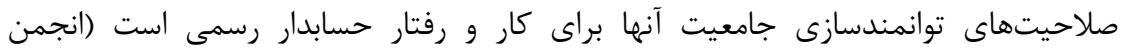

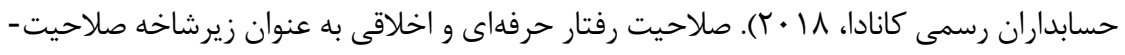
هاى توانمندسازى اشاره به رفتار در قالب صداقت، درستكارى، اعتبار، اعتماد به نفس و واستقال إنال

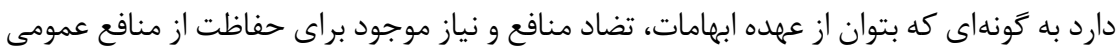

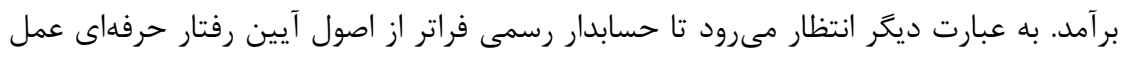

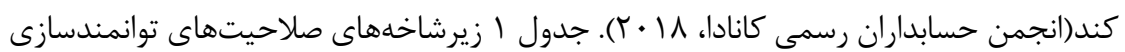

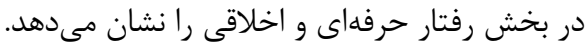

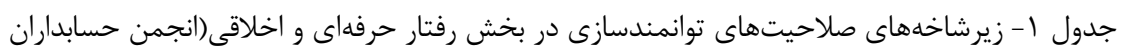

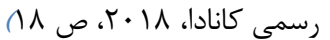

\begin{tabular}{|c|c|c|}
\hline اعمال مورد نياز & صلاحيت & حوزه صلاحيت \\
\hline شا شالفايى موقعيتهاى داراى مشكلات اخلاقى بالقوه & \multirow{3}{*}{ استفاده از فرآيند استدلال } & \multirow{15}{*}{ صربوط به رفتار هاى } \\
\hline 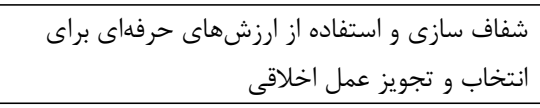 & & \\
\hline مقامات حقوش موضوع اخلاقى به سطوح بالاتر مديريتى، & & \\
\hline ابراز صداقت و درستكارى & \multirow{5}{*}{ اتخاذ ارزشهاى حرفه } & \\
\hline اعمال صلاحيت و مراقبت حرفهاى & & \\
\hline رعايت بىطرفى، استقلال و احتياط حرفهاى & & \\
\hline يادگيرى مستمر و آكاهى از روندهاى جديد و & & \\
\hline موضوعات روز & & \\
\hline 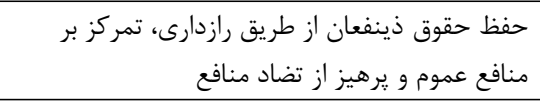 & \multirow{3}{*}{ 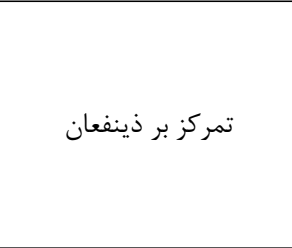 } & \\
\hline حفظ و افزايش شهرت حرفه & & \\
\hline مشردوست فعاله، مسئوليت اجتماعى وحفظ از قبيل فعاليتهاى محيط زيست & & \\
\hline رعايت قوانين و مقررات & \multirow{4}{*}{ رعايت قوانين، استانداردهاى } & \\
\hline رعايت قوانين مربوط به رفتار حرفهاى & & \\
\hline اعمال استانداردهاى حرفهاى & & \\
\hline رعايت سياستهاى سازمانى & & \\
\hline
\end{tabular}


دو فصلنامه حسابدارى ارزشى و رفتارى، سال ينجم، شماره دهم، پِاييز و زمستان وجسا

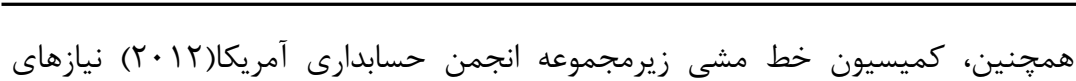

اخلاقى كه دانشآموختگان حسابدارى در دوره كارى خود روبرو مىشوند را بررسى و در اين

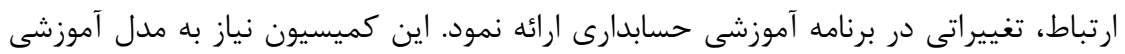
جديد براى محيط تجارى مدرن و حرفه حسابدارى كه در حال توسعه است، شناسايى كرد.

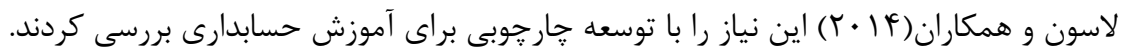

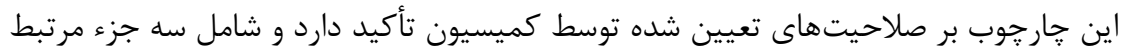
با يكديخر است: الف) صلاحيتهاى بنيادى ب) صلاحيتهاى اصلى مديريت ج) صلاحيتهاى حسابدارى كه مىبايست در طول زمان از طريق تحصيل، آموزش و تجربه كارى توسعه و تكامل

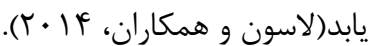

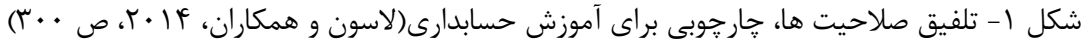

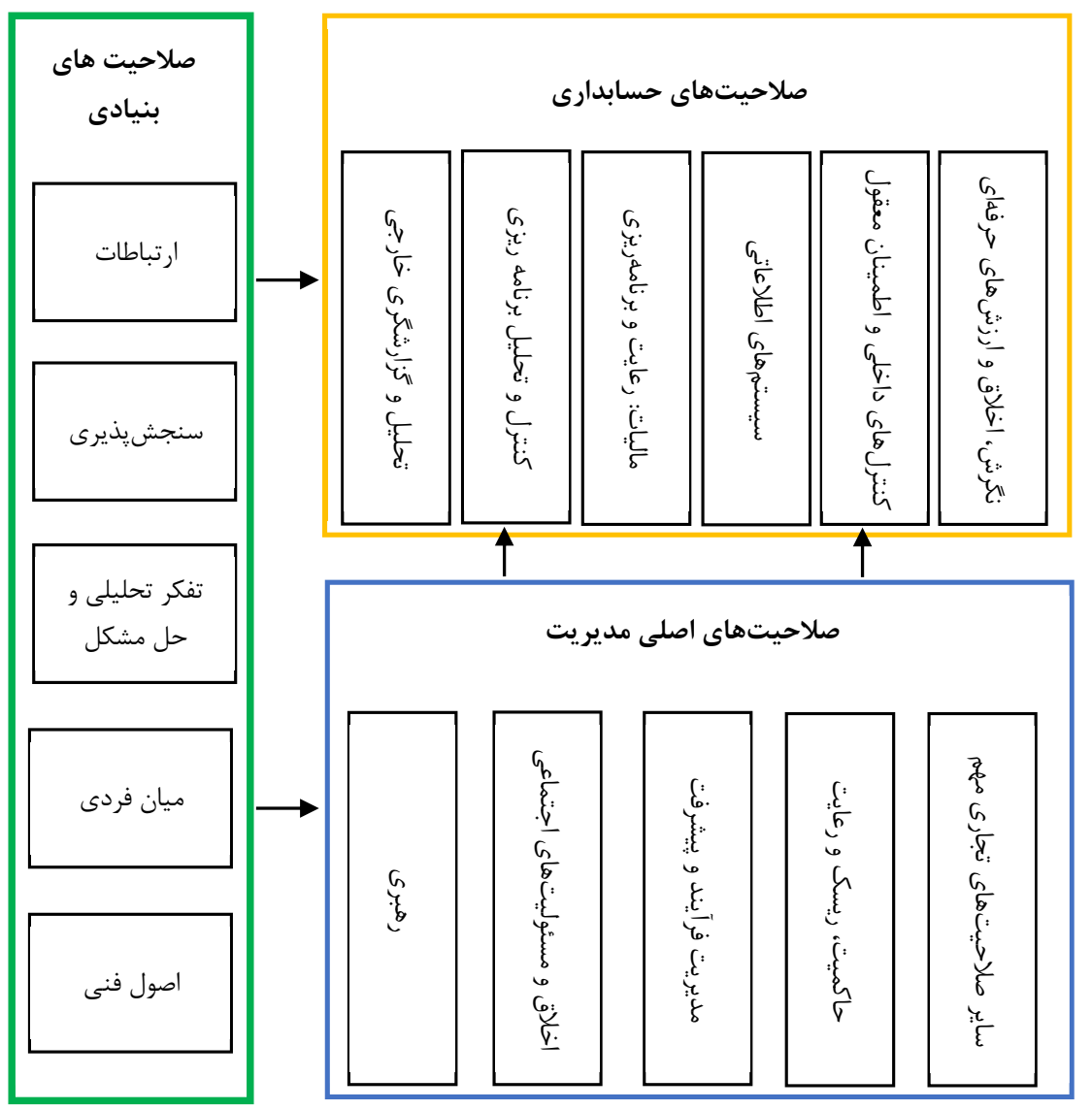




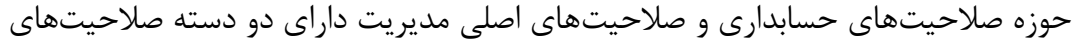

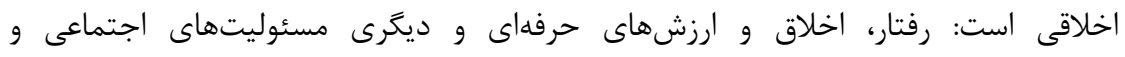

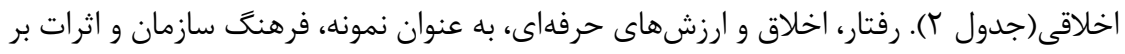

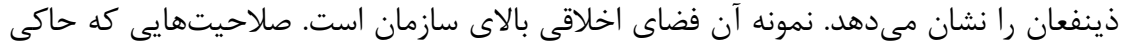

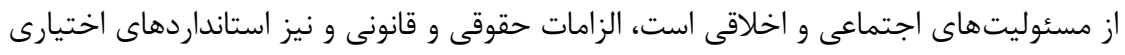
را شامل مىشود. مثالهايى از صلاحيت مسئوليت اجتماعى و اخلاقى شامل جزئئيات سيستم

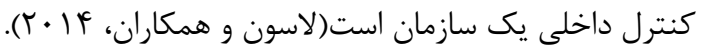

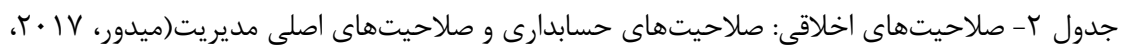

\begin{tabular}{|c|c|}
\hline \multicolumn{2}{|c|}{ ص } \\
\hline مسئوليتهاى اجتماعى و اخلاقى & رفتار، اخلاق و ارزشهاى حرفهاى \\
\hline مباشرت زيست محيطى & صلاحيت فنى \\
\hline شرايط و عرف نيروى كار & رفتار حرفهاى \\
\hline حقوق انسانى & رويه حرفهاى \\
\hline امنيت و سلامت & كمال طلبى \\
\hline مشاركتهاى اجتماعى & مسئوليت اجتماعى \\
\hline تبعيت جهانى & شك گرايى حرفه اى \\
\hline آيين رفتار حرفهاى & بى طرفى \\
\hline تفاوتهاى اخلاقى و حقوقى & قضاوت حرفهاى \\
\hline افشاكرى & خلاقيت \\
\hline الزامات قانونى & نوآورى \\
\hline & فرهنَ اخلاقى \\
\hline
\end{tabular}

با عنايت به مطالب فوق، در يزوهش حاضر با استفاده از صلاحيتهاى اخلاقى ارائه شده

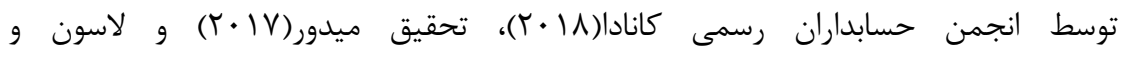

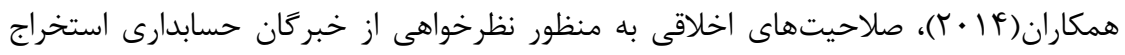

در خصوص شيوه آموزش صلاحيتهاى اخلاقى، تحقيقات مربوط به آموزش صلاحيتهاى

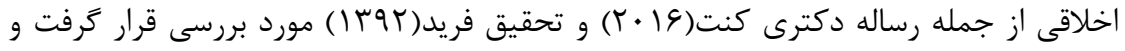

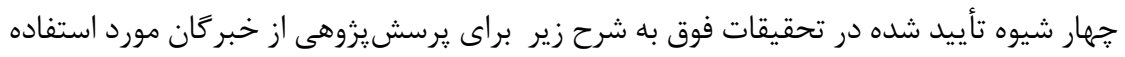

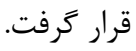


1- آموزش شناختى اخلاق' : در اين شيوه معماها يا موضوعات خالشبرانكَيز اخلاقى، در حوزه-

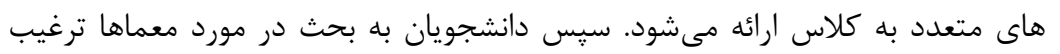

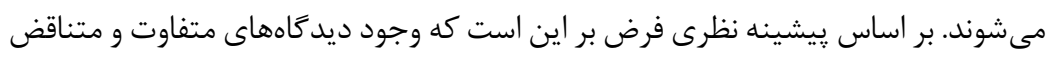

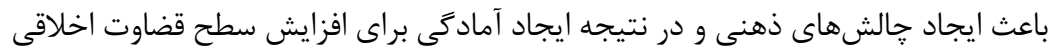

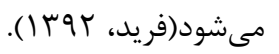

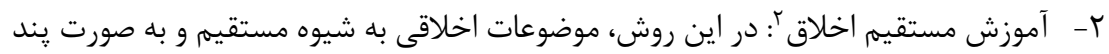

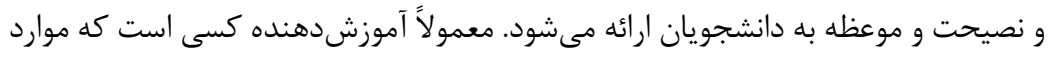

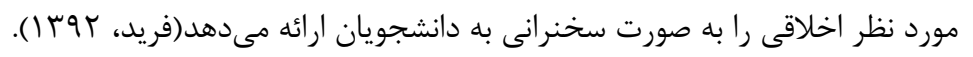

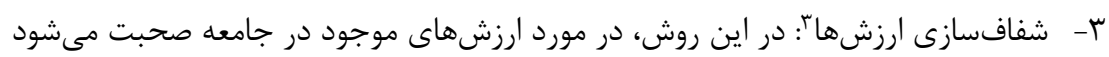

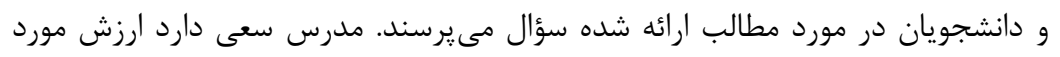

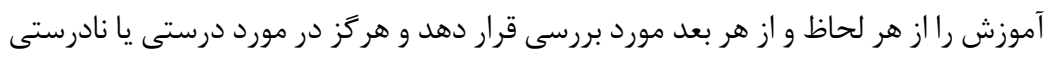

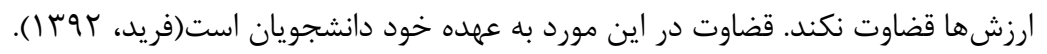

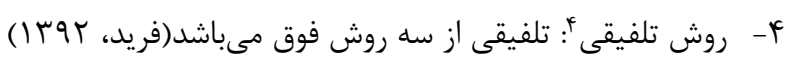

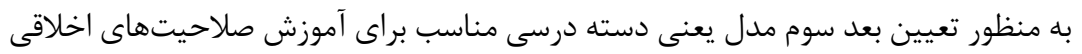

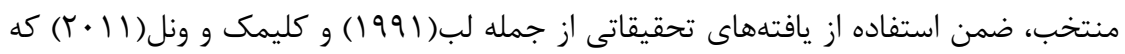

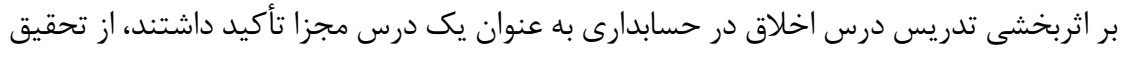

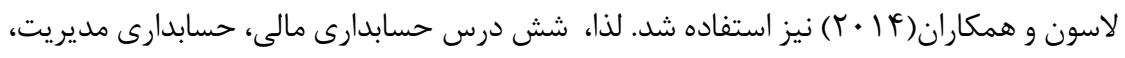

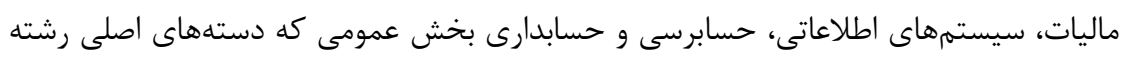

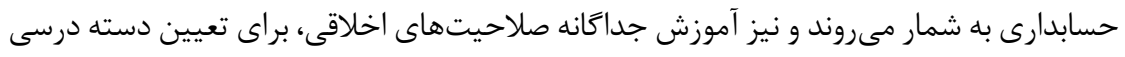

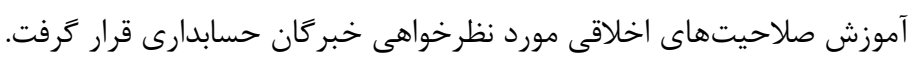

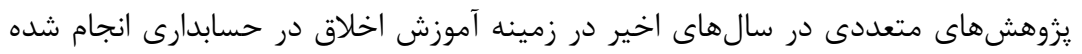

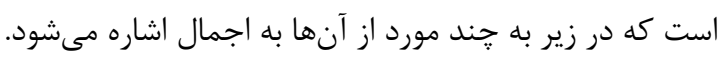

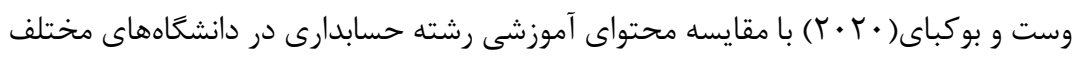

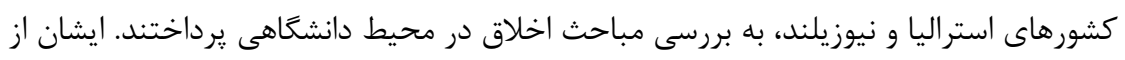

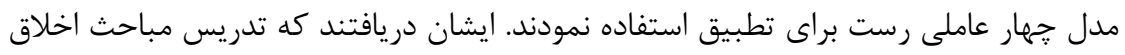

${ }^{1}$ Cognitive moral education

${ }^{2}$ Direct method

${ }^{3}$ Value clarification

${ }^{4}$ Combinational method 
در محيط دانشكاهى بر دو عامل شناخت موضوع و قضاوت اخلاقى تأكيد دارد و نيت اخلاقى و

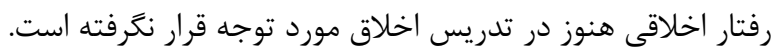

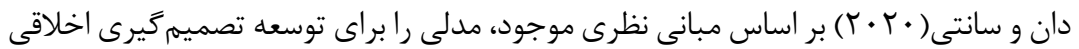

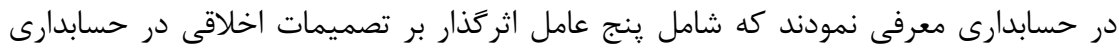

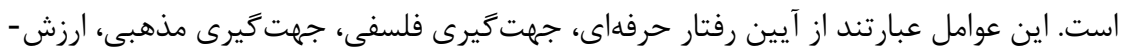

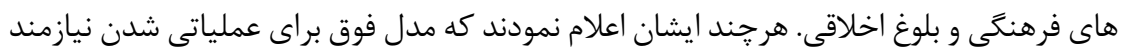
تحقيقات يزوهشى مى مباشد.

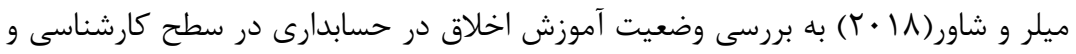

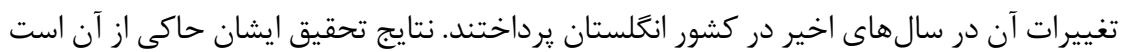
كه دامنه يوشش آموزش اخلاق تغيير محسوسى در دو دهه اخير نداشته و محتواى كنونى آموزش

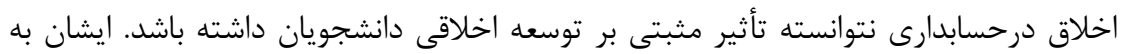

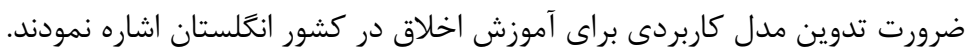

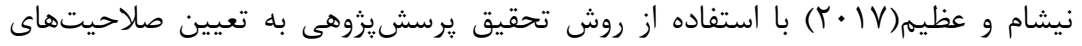

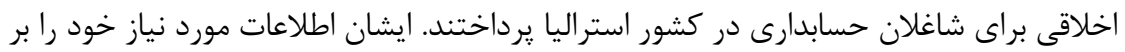

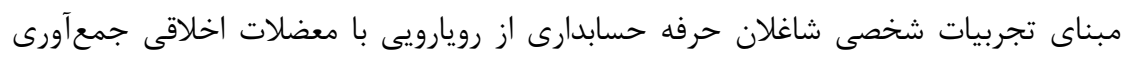

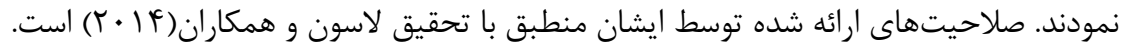

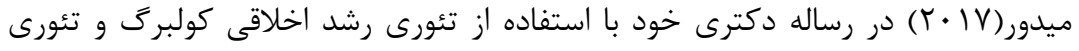

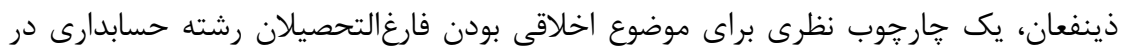

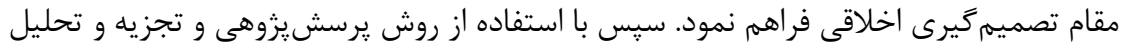

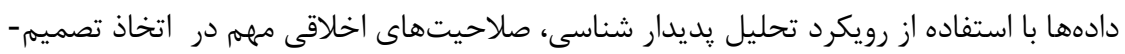

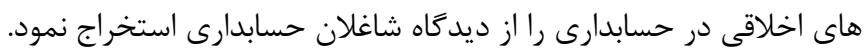

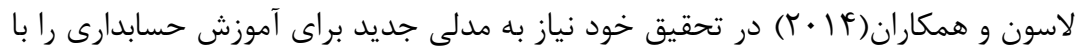

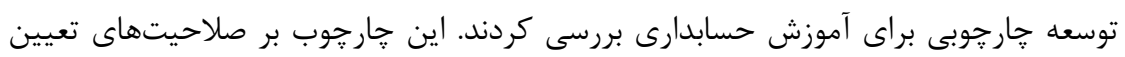

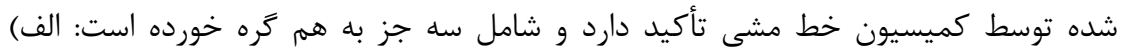
صلاحيتهاى بنيادى ب) صلاحيتهاى اصلى مديريت ج) صلاحيتهاى حسابدارى. صلاحيت-

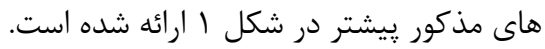

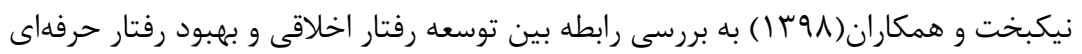

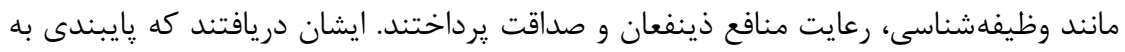

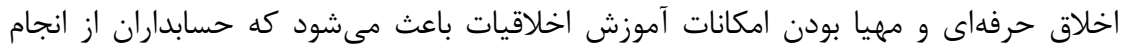

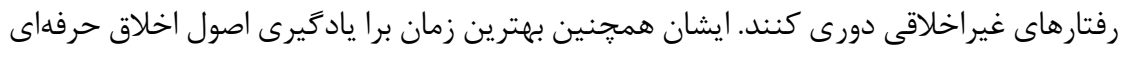


را دوره دانشجويى معرفى نمودند كه در بركيرنده شروع فعاليت برقرارى ارتباط حرفهاى با ذينفعان و همرييشان است.

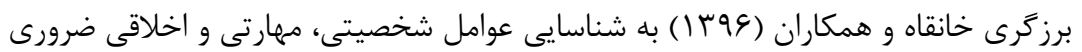

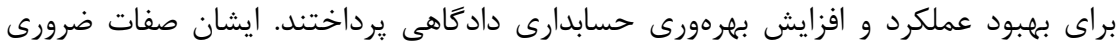

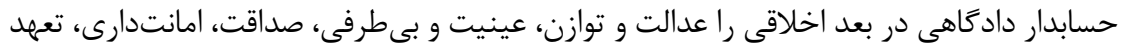

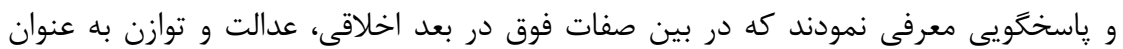
مهمترين شاخص شناخته شده است.

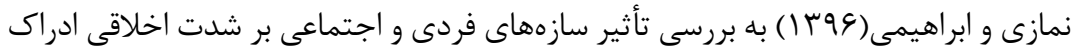

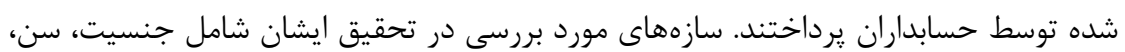
سطح تحصيلات، رشته تحصيلى و ديندارى مىباشد. نتايج تحقيق بيانكر تأثير منفى و معنادار

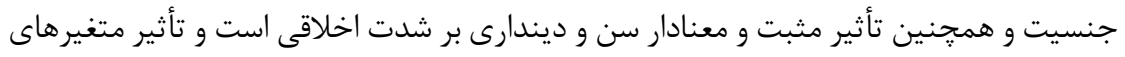
سطح تحصيلات و رشته تحصيلى معنادار نيست. اگرجه مطالعات بالا از جنبههاى مختلف ادبيات اخلاق حسابدارى را كسترش دادهاند اما

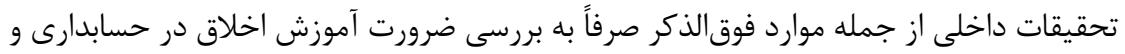

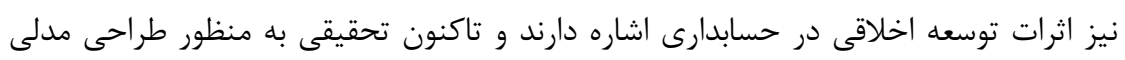

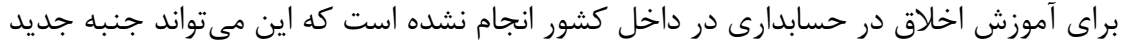
بودن تحقيق حاضر را نمايان سازد. جدول r- دسته بندى صلاحيتهاى اخلاقى، شيوهائ سارد آموزش و دسته درسى آموزش،

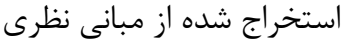

\begin{tabular}{|c|c|c|c|}
\hline \multicolumn{4}{|c|}{ صلاحيتهاى اخلاقى } \\
\hline منابع مورد استفاده براى استخراج عوامل & 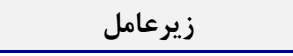 & 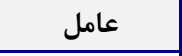 & 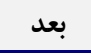 \\
\hline انجمن حسابداران رسمى كاناد(1) • r) & تعيين و تشخيص موضوعات & \multirow{3}{*}{ 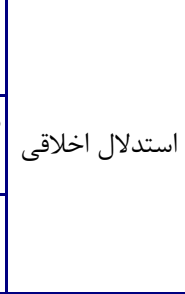 } & \multirow{5}{*}{ 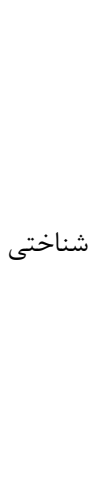 } \\
\hline 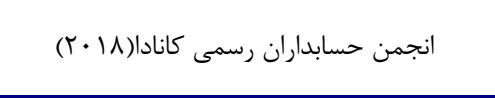 & شفاف سازى اخلاقى معضلات & & \\
\hline انجمن حسابداران رسمى كاناد(N ( ) ). & 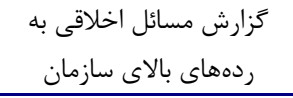 & & \\
\hline انجمن حسابداران رسمى كاناد(1) • (T) & 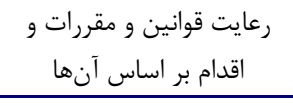 & \multirow{2}{*}{ حرفه و سياستاردهاى } & \\
\hline 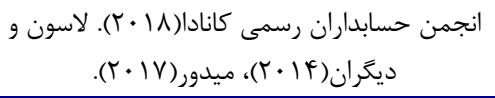 & استانداردهاى حرفه جانه & & \\
\hline
\end{tabular}




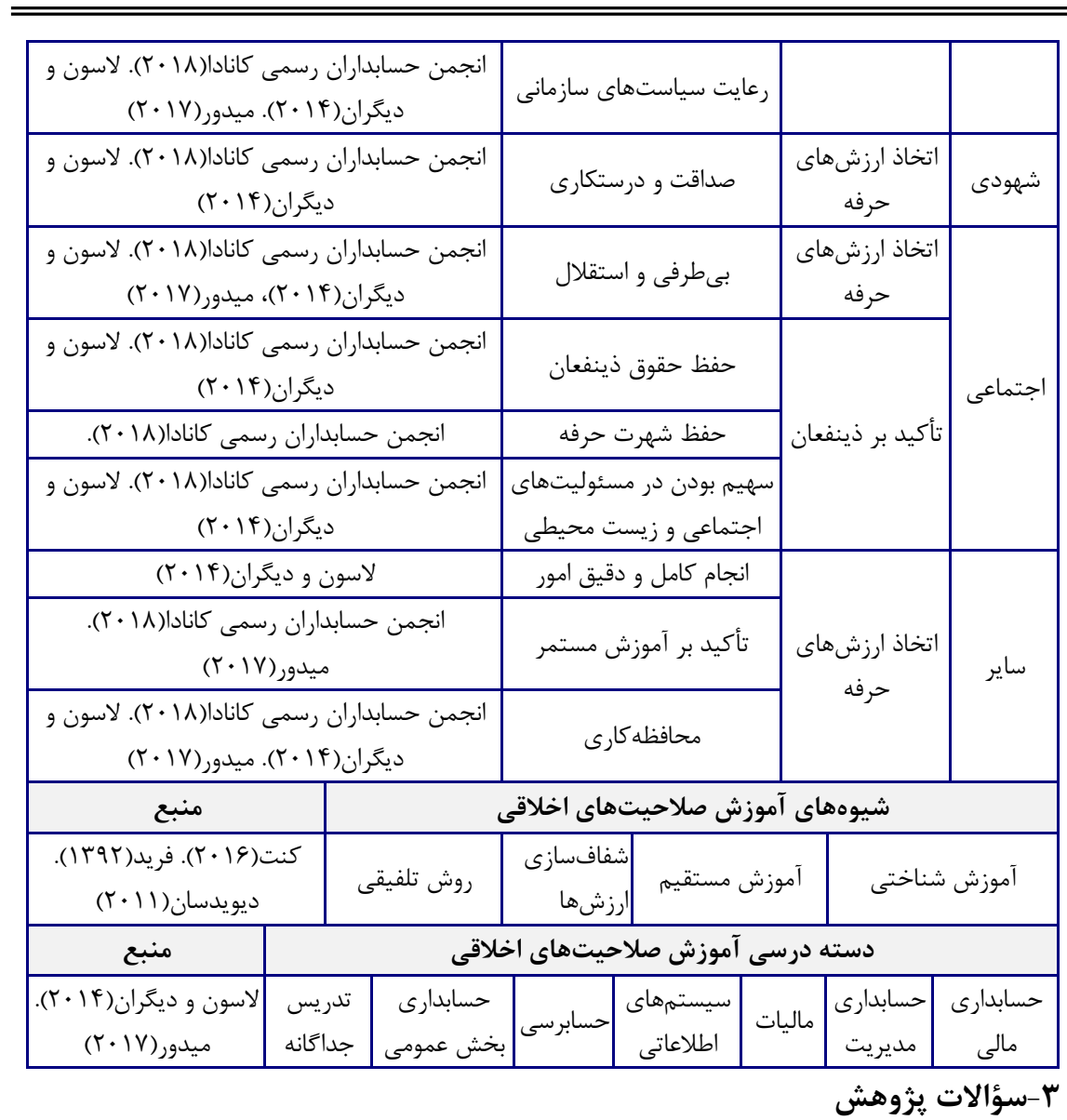

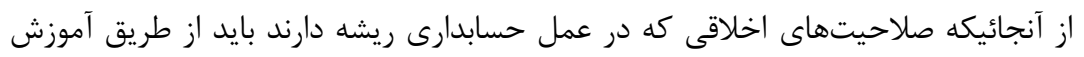

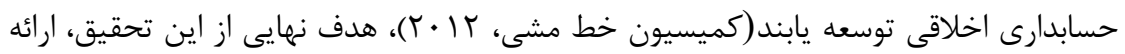

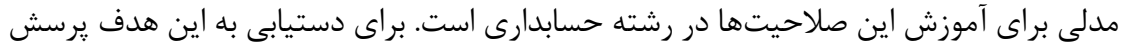
اصلى اين تحقيق به شرح زير بيان شده است:

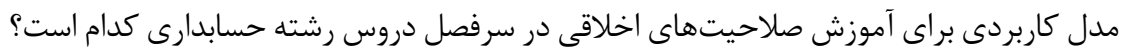
براى ياسخكَيى به يرسش فوق، سه بعد شناخت صلاحيتهاى اخلاقى، شيوه آموزش و دسته

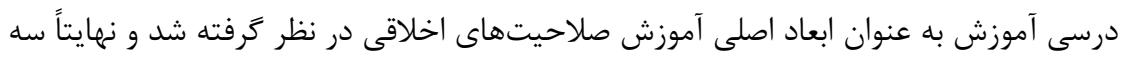
يرسش فرعى زير طراحى گرديد: يرسش فرعى ا: صلاحيتهاى اخلاقى مورد نياز براى اتخاذ تصميم اخلاقى در حسابدارى 
يرسش فرعى r: صلاحيتهاى اخلاقى منتخب به جه شيوهاى بايد در رشته حسابدارى آموزش داده شوند؟

يرسش فرعى r: صلاحيتهاى اخلاقى منتخب در كدام يك از دسته هاى درسى رشته حسابدارى

$$
\text { بايد آموزش داده شوند؟ }
$$

\section{F F-روششناسى يزوهش}

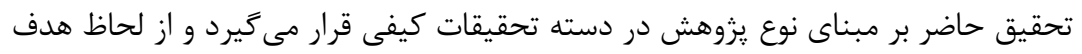
از نوع تحقيقات اكتشافى است. در اين تحقيق تلاش مىشود تا صلاحيتهاى اخلاقى مورد نياز براى تصميم گيرى اخلاقى در حسابدارى، شيوه آموزش و دسته درسى مناسب از رشته حسابدارى

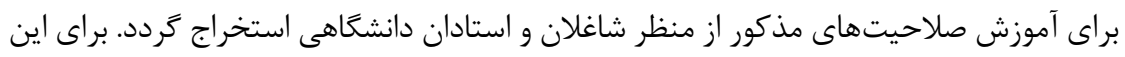
منظور، از روش تحقيق دلفى فازى استفاده گرديد. روش دلفى براى بررسى قضاوت خبر كان مورد استفاده قرار مى گيرد و هدف از آن، دسترسى به مطمئنترين توافق گروهى خبر گان درباره

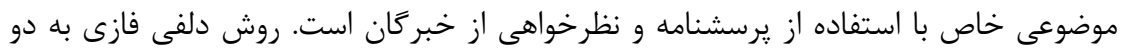
شكل تك مرحلهاى و جند مرحلهاى اجرا مىشود كه در اين تحقيق از روش تك مرحلهاى استفاده گرديد. در روش تك مرحلهاى تنها يك دور يرسشنامه طراحى و توزيع مىشود لذا تنوع آراى

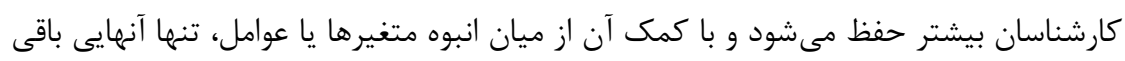

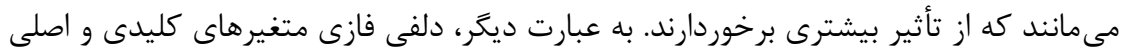

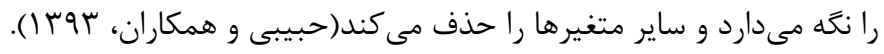

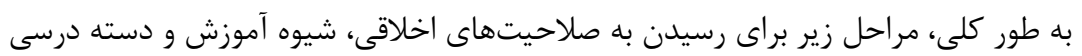

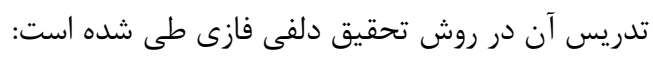
الف- مطالعه مبانى نظرى: شناسايى صلاحيتهاى اخلاقى، شيوه آموزش و دسته درسى تدريس

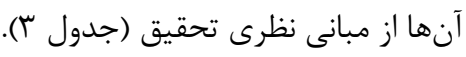

ب- طراحى يرسشنامه محقق ساخته: استخراج اطلاعات از مبانى نظرى كه به نظر يزوهشگر با

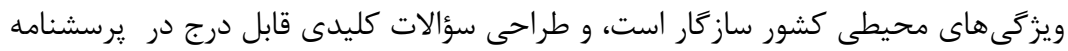

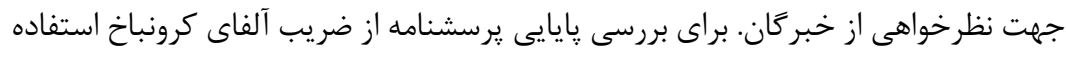

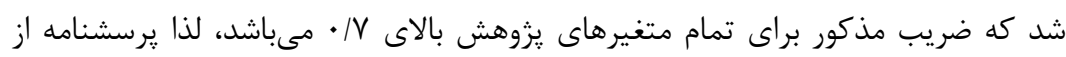
קايايى قابل قبول برخوردار است. به منظور تعيين روايى، يرسشنامه طراحى شده در اختيار

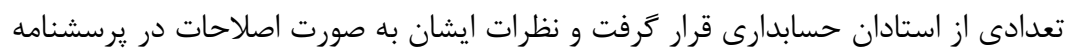

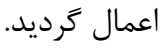


ج- نظرخواهى از خبر كان حسابدارى: توزيع برسشنامه تنظيم شده با طيف ليكرت ه رتبهاى در

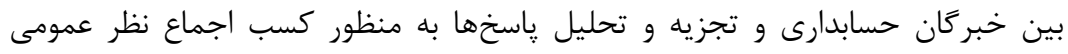

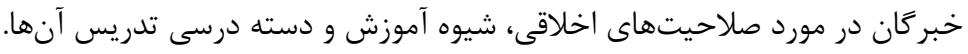

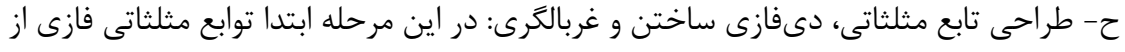

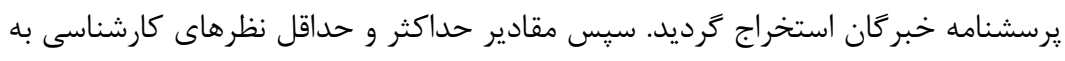

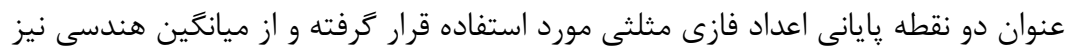
به عنوان درجه عضويت اعداد فازى مثلثى استفاده شد. در مرحله بعد، اعداد فازى مثلثى باديا

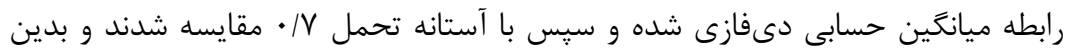

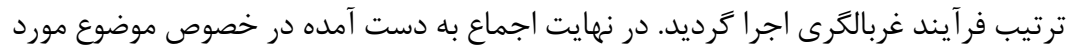

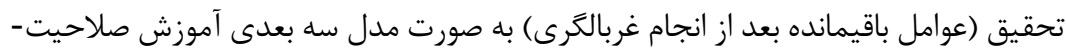
هاى اخلاقى ارائه كرديد. با توجه به اينكه هدف كلى اين تحقيق دستيابى به مدلى كاربردى بدرئ براى آموزش صلاحيتهاى

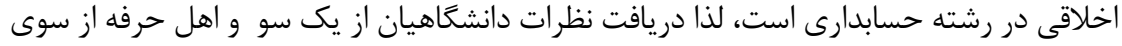

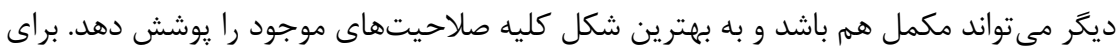

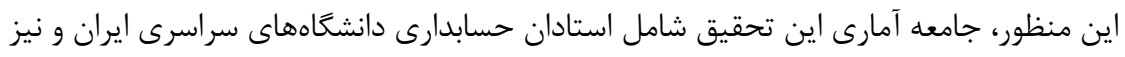

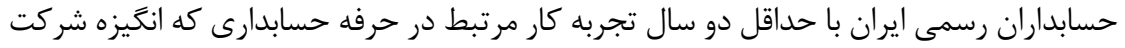

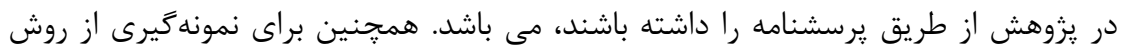

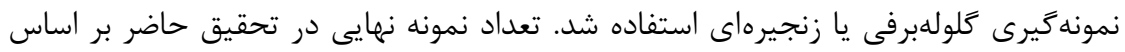
نمونه كيرى كيفى شامل • لها نفر است.

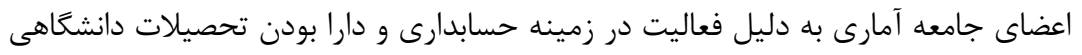

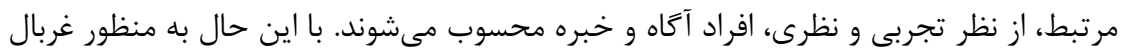

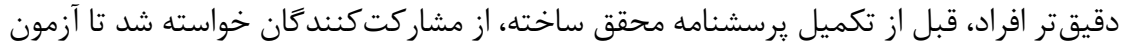

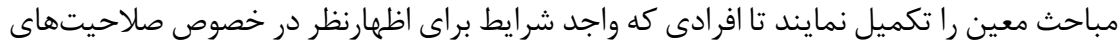

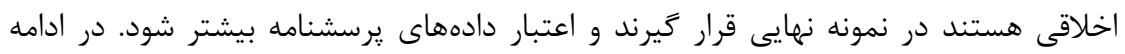

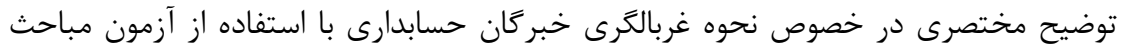

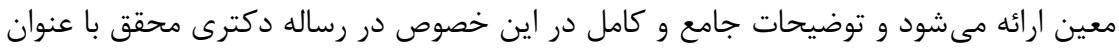

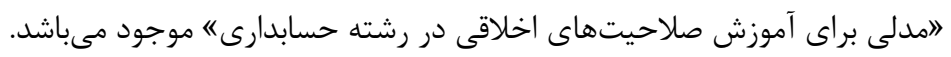

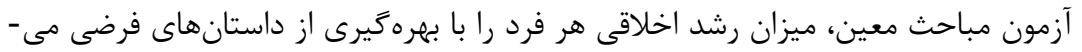

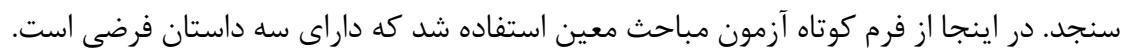

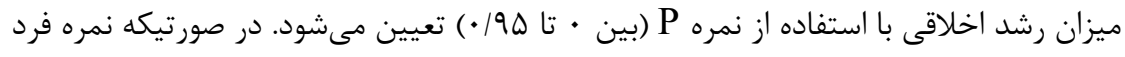


بين هD/• تا ه9/• باشد، سطح قضاوت اخلاقى وى بالا مىباشد(كديور، (9با). لذا با توجه به

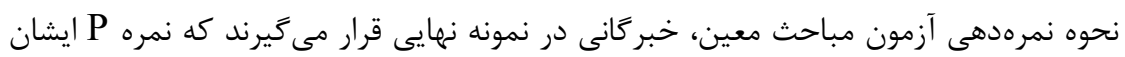

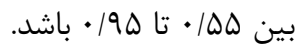
بر اساس نمونه

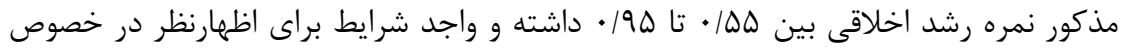
صلاحيتهاى اخلاقى شناخته شدند.

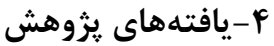

در فرآيند اجراى تحقيق، \& F صلاحيت اخلاقى در \& بعد شناختى، شهودى، اجتماعى و ساير،

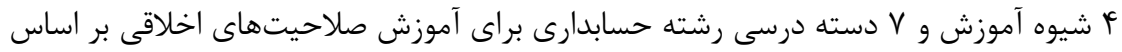

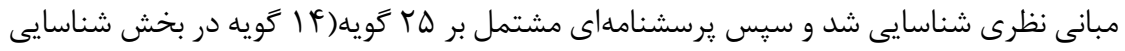

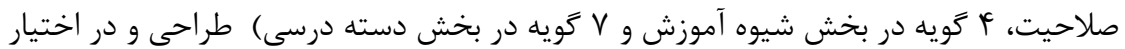
•ها نفر از خبركان حسابدارى قرار كرفت. يرسشنامهها به صورت دستى از طريق مراجعه

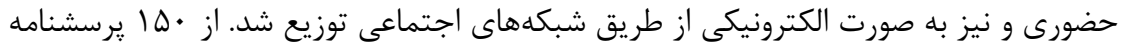

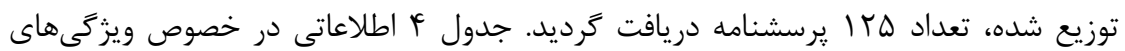
فردى ياسخدهندكان را نمايش مى تهده:

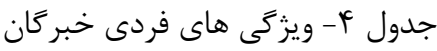

\begin{tabular}{|c|c|c|c|c|c|c|c|c|c|}
\hline \multicolumn{2}{|c|}{ جمع خبر كان } & \multicolumn{2}{|c|}{ رسم حسابدار } & \multicolumn{2}{|c|}{ حسابداران } & \multicolumn{2}{|c|}{ حسابدارى استادان } & \multirow{2}{*}{ شرح } & \multirow{2}{*}{ متغير } \\
\hline فراوانى & فراوانى | & فراوانى & فراوانى & فراوانى & | فراوانى | & فراوانى & | فراوانى | & & \\
\hline . & . & . & . & . & . & . & . & كمتر از & \multirow{7}{*}{ سن } \\
\hline rr & F. & . & . & $r \Delta / r$ & TF & TF/V & 19 & $r \Delta-r \Delta$ & \\
\hline$r q / \Lambda$ & 48 & $F \Delta / \Delta$ & $\Delta$ & $F \mid / T$ & $r \Lambda$ & $r N / r$ & $\pi$ & $F \Delta-r q$ & \\
\hline$T r / T$ & rq & 9 & 1 & $T r / 1$ & 10 & TN/T & Ir & $\Delta \Delta-\xi q$ & \\
\hline$\Lambda$ & 1. & $F \Delta / \Delta$ & 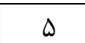 & $1 / 4$ & 1 & $N / V$ & $r$ & $9 \Delta-\Delta \varphi$ & \\
\hline . & . & . & . & . & . & . & . & بيش از 9ه| & \\
\hline $1 .$. & $1 T \Delta$ & $1 .$. & 11 & $1 .$. & 91 & $1 .$. & Fq & جمع & \\
\hline$r q / r$ & $4 q$ & $T V / T$ & r & $r q / V$ & TV & $41 / r$ & 19 & زن & \multirow{3}{*}{ جنسيت } \\
\hline $4 \cdot 11$ & ve & $V T / V$ & $\Lambda$ & $9 \cdot 1 \pi$ & il & $\Delta \Lambda / V$ & TV & مرد & \\
\hline $1 .$. & Ira & $1 .$. & 11 & $1 .$. & 91 & $1 .$. & 49 & جمع & \\
\hline
\end{tabular}


دكترباباجانى و همكاران، مدل سه بعدى آموزش صلاحيتحهاى اخلاقى در رشته حسابدارى

\begin{tabular}{|c|c|c|c|c|c|c|c|c|c|}
\hline$r T / F$ & $r \Lambda$ & . & $\cdot$ & $r q / 4$ & $r \cdot$ & $I V / F$ & $\wedge$ & $\omega_{-} \cdot$ & \multirow{5}{*}{ ندريس /كار (سال) } \\
\hline Tr/A & il & $1 N / r$ & $r$ & $r q / V$ & TV & $r 9 / 1$ & IT & $1 \cdot-\Delta$ & \\
\hline$r q / 9$ & rV & $r V / T$ & $r$ & TE/D & 11 & $M F / \Lambda$ & 19 & $r \cdot-1$. & \\
\hline $1 Q / T$ & 19 & $\Delta F / \Delta$ & 4 & $f / f$ & $r$ & $T I / V$ & 1. & بيش از •r & \\
\hline $1 .$. & $1 T \Delta$ & $1 .$. & 11 & $1 .$. & $9 \wedge$ & $1 .$. & fq & جمع & \\
\hline$r V / T$ & rF & $1 N / T$ & $r$ & $\Delta / 9$ & f & $9 \cdot 19$ & $r \Lambda$ & دكترى & \multirow{4}{*}{ تحصيلات } \\
\hline$G T / F$ & $\vee \wedge$ & $\Lambda 1 / \Lambda$ & 9 & $V \Delta$ & 01 & rq/l & 11 & \begin{tabular}{|c|} 
كارشناسى \\
ارشد \\
\end{tabular} & \\
\hline $1 \cdot / 4$ & Ir & . & $\cdot$ & $19 / 1$ & Ir & . & . & كارشناسى & \\
\hline $1 .$. & Ird & $1 \ldots$ & 11 & $1+$. & 91 & $1 .$. & fq & جمع & \\
\hline
\end{tabular}

نتايج مربوط به تجزيه و تحليل روش دلفى فازى براى شناسايى صلاحيتهاى اخلاقى در

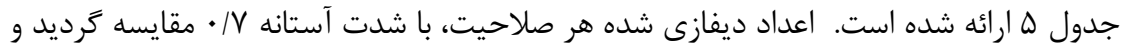

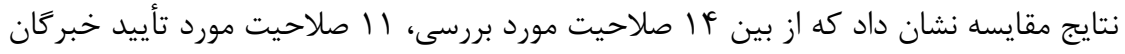

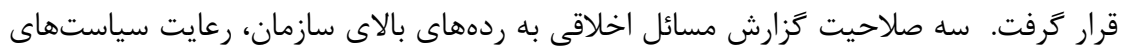

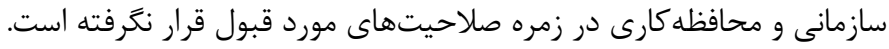
جدول ه- نتايج دلفى فازى براى شناسايى صلاحيتهاى احداى اخلاقى

\begin{tabular}{|c|c|c|c|}
\hline نتيجه & مقدار قطعى & عدد فازى مثلثى & زيرعامل \\
\hline \multicolumn{4}{|c|}{ 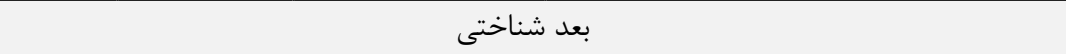 } \\
\hline تأييد & $\cdot / 199$ & $(\cdot / 09 ، \cdot 1 \wedge r \cdot \cdot / 90)$ & تعيين و تشخيص موضوعات اخلاقى \\
\hline تأييد & $\cdot 1 \Lambda$ & $(\cdot 19 \cdot ، \cdot 114 \cdot \cdot 199)$ & شفافسازى اخلاقى معضلات در محيط كار \\
\hline o & .194 & $(\cdot|q| ،|q \mu, \cdot| \Lambda \mu)$ & كزارش مسائل اخلاقى به ردههاى بالاى سازمان \\
\hline تأييد & $\cdot / \Lambda$ & $(\cdot|9| \cdot \cdot 110 \cdot \cdot / 94)$ & رعايت قوانين و مقررات و اقدام بر اساس آنها \\
\hline تأييد & $\cdot \operatorname{lAt}$ & $\left(\cdot / 9 r_{،} \cdot 11 \mathrm{~V} \cdot 199\right)$ & رعايت همه جانبه استانداردهاى حرفه \\
\hline ر & $\cdot 191$ & $(\cdot / 44.199 .19 \cdot)$ & رعايت سياستهاى سازمانى \\
\hline \multicolumn{4}{|c|}{ بعد شهودى } \\
\hline تأييد & $\cdot / \Lambda \mathrm{V}$ & $(\cdot / V \cdot 1 \cdot / 9 f \cdot \cdot / 97)$ & صداقت و درستكارى \\
\hline \multicolumn{4}{|c|}{ 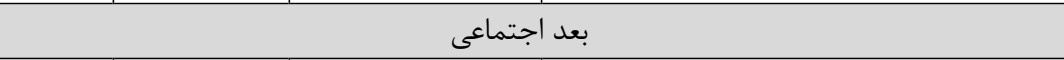 } \\
\hline تأييد & $\cdot / \Lambda \Delta$ & $\left(\cdot 19 V_{1} \cdot 191 ، \cdot 199\right)$ & بى طرفى و استقلال \\
\hline تأييد & $\cdot / \Lambda$ & $(\cdot / 9 \mid ، \cdot 11 \Delta \cdot \cdot 19 \Delta)$ & حفظ حقوق ذينفعان \\
\hline تأييد & $\cdot / \mathrm{VA}$ & $(\cdot / 09 ، / 114 ، / 94)$ & حفظ شهرت حرفه \\
\hline تأييد & $\cdot / \mathrm{V}$ & $(\cdot / 4 \wedge ، / V r \cdot \cdot / \wedge q)$ & سهيم بودن در مسئوليتها اجتماعى و \\
\hline
\end{tabular}


دو فصلنامه حسابدارى ارزشى و رفتارى، سال ينجم، شماره دهم، پِاييز و زمستان وجسا

\begin{tabular}{|c|c|c|c|}
\hline \multicolumn{4}{|c|}{ ساير } \\
\hline تأييد & $\cdot / \mathrm{V} \wedge$ & $\left(\cdot / \Delta \Lambda ، / 1 \Lambda r^{\prime} \cdot / 9 \Delta\right)$ & انجام كامل و دقيق امور \\
\hline تأييد & $\cdot / V F$ & $(\cdot / \Delta \Delta, \cdot / V q . \cdot / 91)$ & تأكيد بر آموزش مستمر \\
\hline رد & $\cdot 109$ & $(\cdot / r T \cdot \cdot|\Delta S \cdot \cdot| \Lambda \cdot)$ & محافظه كارى \\
\hline
\end{tabular}

در ادامه توضيح مختصرى در خصوص صلاحيتهاى منتخب براى آموزش به دانشجويان

$$
\text { رشته حسابدارى ارائه مىشود: }
$$

\section{• تعيين و تشخيص موضوعات اخلاقى}

رست (919 1) مدلى جهار عاملى را بر مبناى مدل رشد اخلاقى كولبرگ ارائه كرد. اين مدل مراحلى را نشان مى دهد كه فرد براى نشان دادن رفتار اخلاقى يشت سر مى حذارد. اولين مرحله

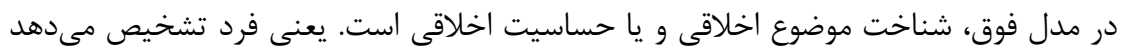

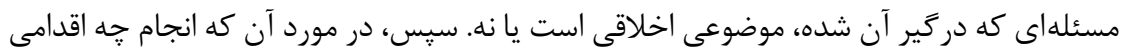
از نظر اخلاقى درست است، قضاوت مى كند. جراكه تا زمانى كه فرد نتواند تشخيص دهد كه در مر ده جه شرايطى بايد قضاوت اخلاقى داشته باشد، نمى تواند عمل درست اخلاقى را انتخاب كند. اين موضوع همان تعيين و تشخيص موضوعات اخلاقى است. • شفافسازى اخلاقى معضلات موجود در محيط كار بر اساس مدل جهمار عاملى رست، يس از آنكه فرد از مسئلهاى كه در آن دركير شده است،

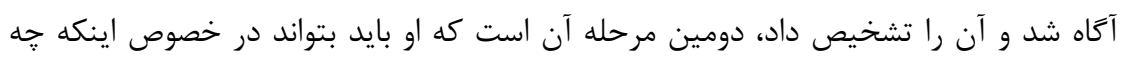
اقدامى از نظر اخلاقى در آن وضعيت درست است، قضاوت كند. قضاوت اخلاقى فرد از اقدام مناسب كه همان شفافسازى معضلات موجود در محيط كار است شامل تفكر انتقادى، استدلال و تأمل در خصوص اصول اخلاقى و تبعات عملى آن مىباشد.

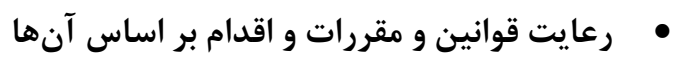
قوانين در حقيقت مجموعهاى از احكام است كه براى نظم بخشيدن به زندگى اجتماعى افراد و رسيدن به رفاه اجتماعى، تدوين شده است. در حرفه حسابدارى، مجموعهاى از قوانين به طور

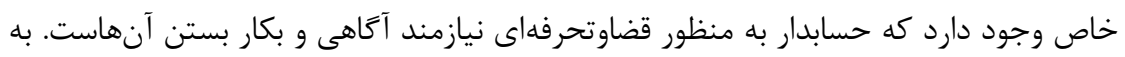

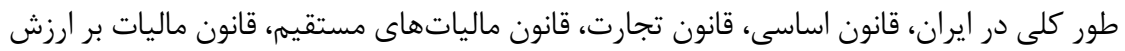

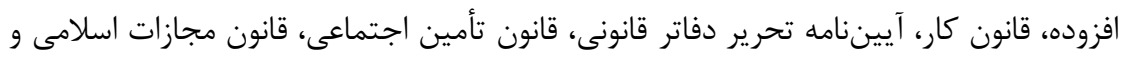

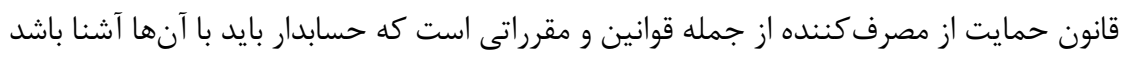


دكترباباجانى و همكاران، مدل سه بعدى آموزش صلاحيتحهاى اخلاقى در رشته حسابدارى

\section{• • رعايت همه جانبه استانداردهاى حرفه}

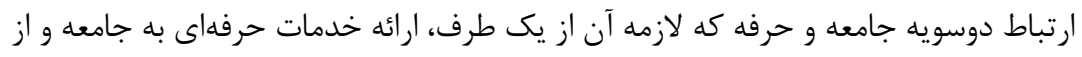

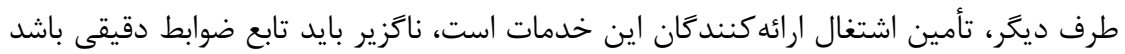

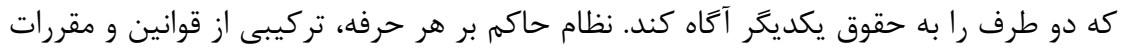

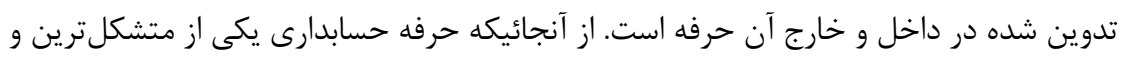

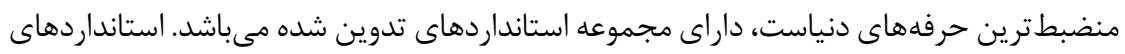

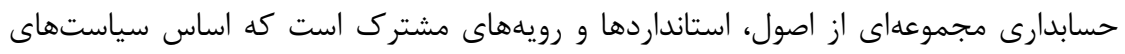

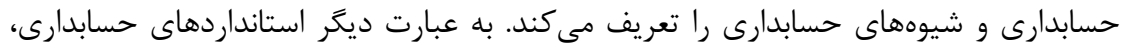

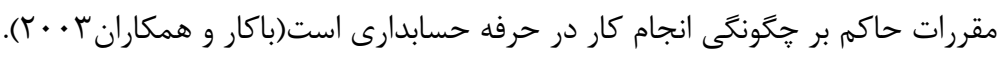

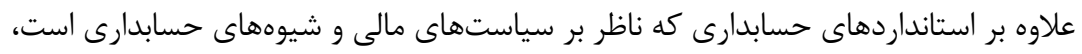

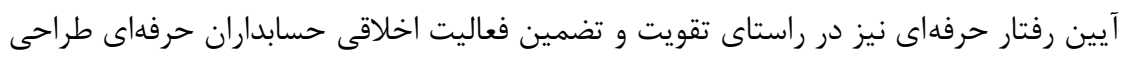

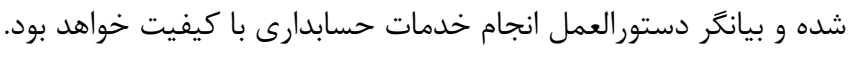

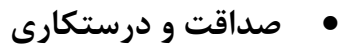

يكى از اصول بنيادى آيين رفتار حرفهاى درستكارى است. بر اساس ائن إس اصل، حسابدار

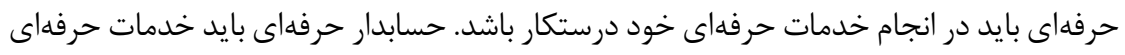

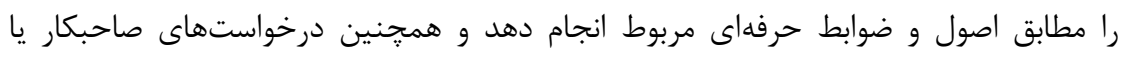

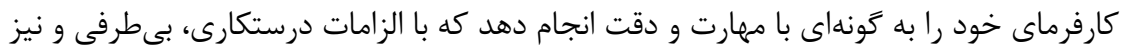

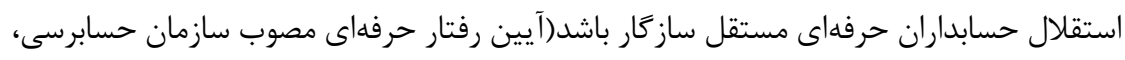

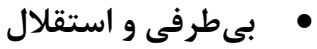

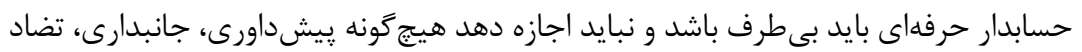

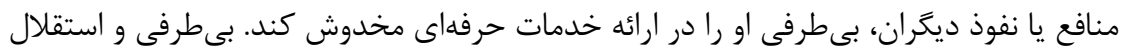

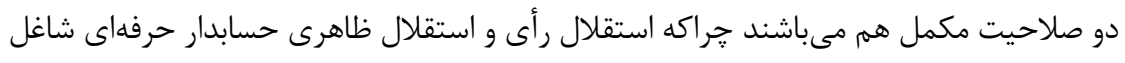

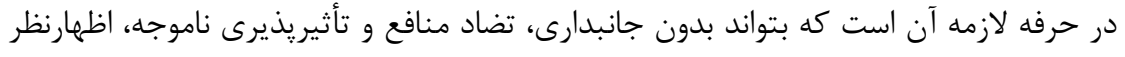

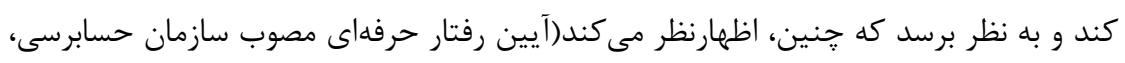




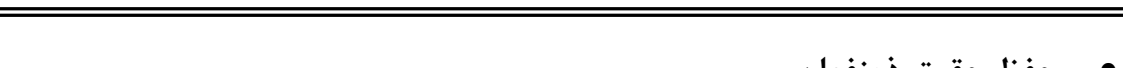

\section{حفظ حقوق ذينفعان}

نظريه ذينفعان به اين نكته اشاره داردكه سازمانها به نفع تمام ذينفعان(به عنوان نمونه،

مالكان، مشتريان، كاركنان، تأمين كنند

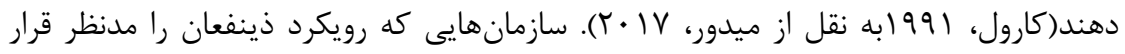
مى دهند، در روابط بين اشخاصى كه در سازمان نفع دارند و توانايى اثركذارى بر موفقيت كسب

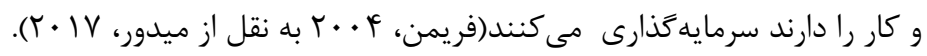
• حفظ شهرت حرفه

تداوم حيات هر حرفه و اشتغال اعضاى آن منوط به نوع خدماتى است كه ارائه مى كند و

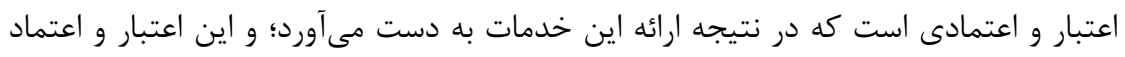

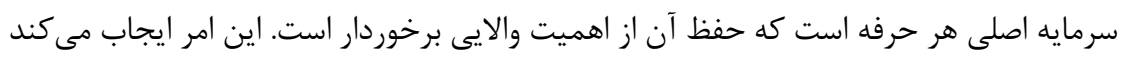

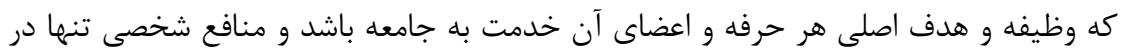

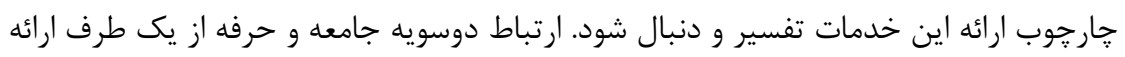
خدمات حرفهاى به جامعه و از طرف ديخر استفاده ارائه كننده اين خدمات است. لذا اين ارتباط بايد تابع ضوابط دقيقى باشد كه دو طرف را به حقوق يكديگر آشنا و آحاه كند. ضوابط رفتارى و

$$
\begin{aligned}
& \text { اخلاقى هر حرفه، مهمترين خطمشى هاى حرفه را تشكيل مى بـهد. }
\end{aligned}
$$

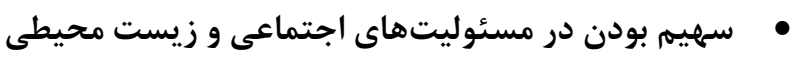

"حفظ حقوق ذينفعان" به عنوان يكى از صلاحيتهاى اخلاقى، داراى ابعاد و مصاديق فراوانى بودي است. با يذيرفتن جامعه و نسلهاى بعد به عنوان ذينفع، مفهوم مسئوليت اجتماعى و زيستمحيطى از اقدامات زيرمجموعه حفظ حقوق ذينفعان به شمار مىرود كه به دليل اهميتى كه امروزه در فضاى كسب و كار جهانى ييدا كرده است، به عنوان يك صلاحيت اخلاقى مجزا مطرح مىشود. ديدكاه مسئوليت اجتماعى از نگرش اخلاقى بر اين فرض است كه فرد به دنبال دستيابى به جامعهاى خوب مىباشد و بر روى الزامات اخلاقى در ارتباط با جامعه تأكيد دارد.

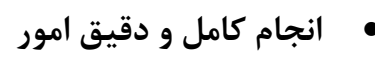

يكى از صلاحيتهاى اخلاقى كه تاكنون مورد توجه قرار نغرفته است، انجام كامل و دقيق امور است. يذيرفتن كامل مسئوليت كارى كه انجام مىشود و انجام كامل و دقيق آن باعث مون شفافسازى هر جه بيشتر فرآيندهاى كارى مى شود كه يكى از نمودهاى تعهد حرفهاى مئ بـاشد.

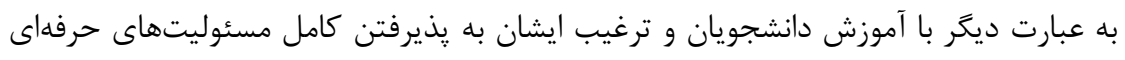
خود، انتيزه ايشان براى حركت در راستاى منافع سازمانى به جاى منافع شخصى افزايش مىيابد. 


\section{• تأكيد بر آموزش مستمر}

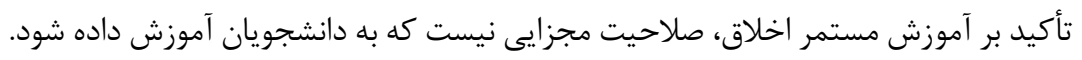

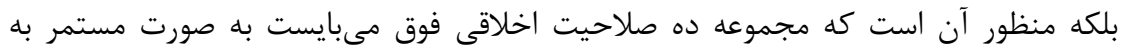

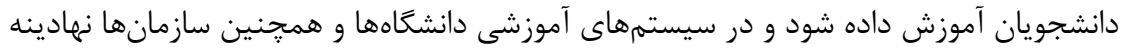

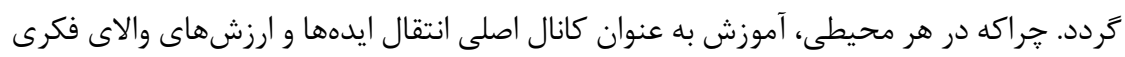
و تحليلى به دانشجويان شناخته مى دود درد.

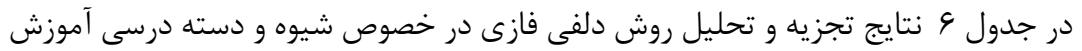

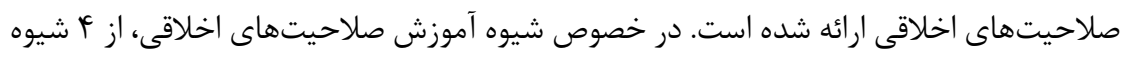

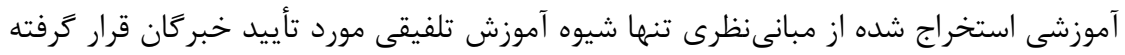

$$
\text { است و ب شيوه ديكر مورد قبول واقع نشد. }
$$

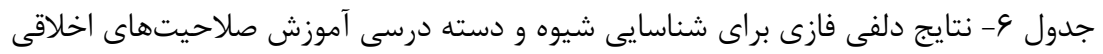

\begin{tabular}{|c|c|c|c|}
\hline نتيجه & مقدار قطعى & عدد فازى مثلثى & شيوه آموزش \\
\hline رد & .194 & $(\cdot / 4 \cdot ، \cdot 190, \cdot / \wedge \mathrm{V})$ & آموزش شناختى اخلاق \\
\hline رد & $\cdot / 49$ & $(\cdot / T) ، / 4 \&$. $\cdot / V I)$ & آموزش مستقيم اخلاق \\
\hline رد & $\cdot 199$ & $(\cdot / 48 \cdot \cdot / V 1 \cdot . / 91)$ & شفافسازى ارزشها \\
\hline تأييد & $\cdot|\Lambda|$ & $(\cdot 194 ، / 199 ، / 90)$ & روش تلفيقى \\
\hline تأييد & $\cdot|V|$ & $(\cdot / \Delta 1 \cdot / V F, \cdot / \wedge 9)$ & تدريس جداكانه \\
\hline ر) & $\cdot / 14 \Delta$ & $(\cdot / \pi) \cdot / 40 \cdot \cdot 19 \Lambda)$ & حسابدارى مالى \\
\hline رد & • & $\left(\cdot / \mu \cdot ، / \Delta F_{،} \cdot / V \Delta\right)$ & حسابدارى مديريت \\
\hline ر & $\cdot 149$ & $\left(\cdot / t t^{\prime} \cdot / 48 \cdot / R \cdot\right)$ & سيستمهاى اطلاعاتى \\
\hline رد & .19. & $(\cdot / r \wedge .|9 r ،| \Lambda I)$ & حسابرسى \\
\hline رد & $\cdot|0|$ & $(\cdot / T V \cdot \cdot|\Delta| \cdot / V G)$ & حسابدارى بخش عمومى \\
\hline رد & $\cdot / 4 q$ & $(\cdot / r \Delta, \cdot / \Delta \cdot, \cdot / V I)$ & ماليات \\
\hline
\end{tabular}

روش تلفيقى همانطور كه از اسمش ييداست، تلفيقى از روش آموزش شناختى اخلاق، روش

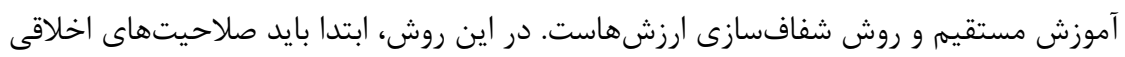

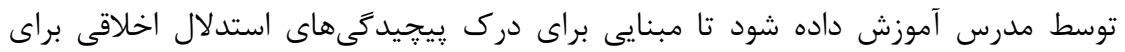

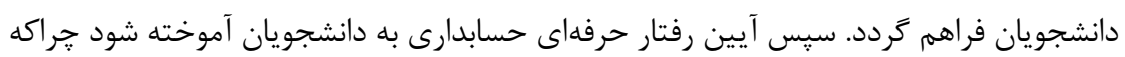

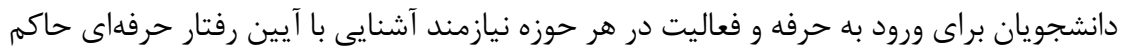
بر آن حوزه مىباشند. در مرحله بعد، مدرس بايد موضوعهاى اخلاقى مطرح در حرفه حرفه مانند 
استقلال، تضاد منافع، معاملات محرمانه، تقلب و غير را با استفاده از تحليل موردى، مورد بحث

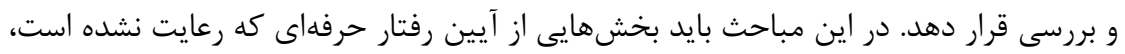

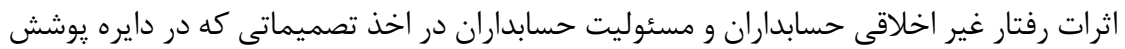

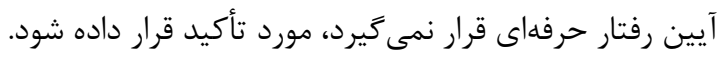

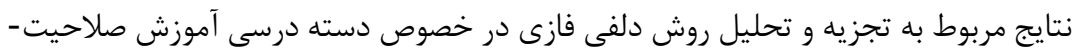

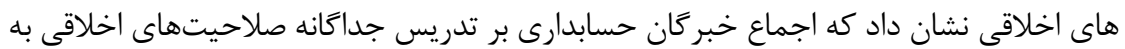
صورت يك درس جداكانه است و تدريس صلاحيتهاى اخلاقى به عنوان سرفصلى از ساير دروس

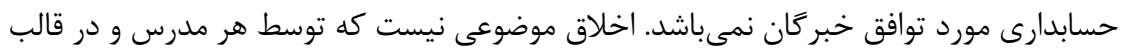

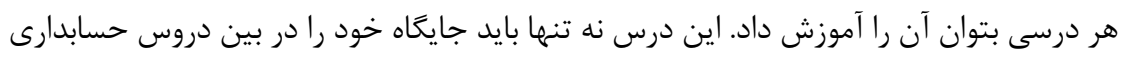
داشته باشد بلكه بايد در قالب يك درس تخصصى اندى حسابدارى نيز مورد توجه ويزه قرار كيرد.

\section{9-نتيجه كيرى و بحث}

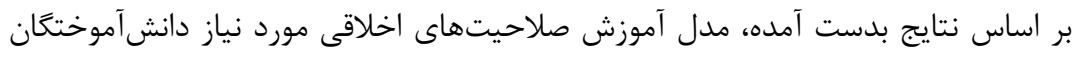

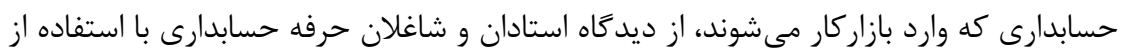

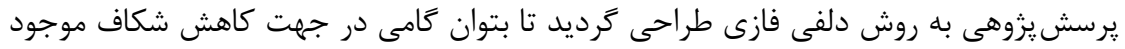

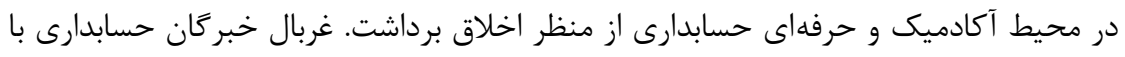

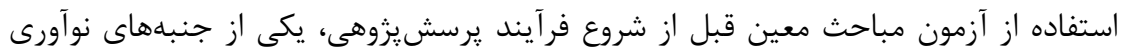
تحقيق حاضر است. در ياسخ به يرسش فرعى اول، يازده صلاحيت اخلاقى شامل تعيين و تشخيص موضوعات

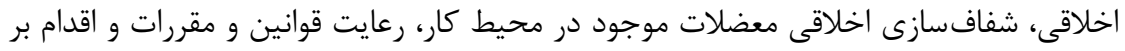
اساس آنها، رعايت همهجانبه استانداردهاى حرفه، صداقت و درستكارى، بى طرفى و استقلال،

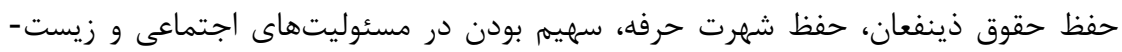

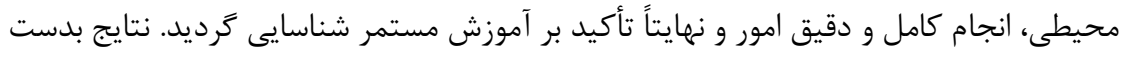
آمده به جز صلاحيتهاى رعايت سياستهاى سازمانى و محافظه كارى كه مورد قبول خبر كان انسان

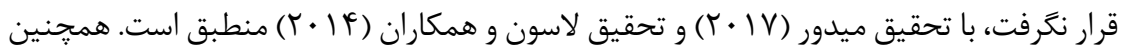

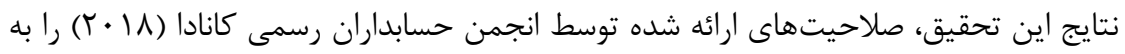
جز صلاحيتهاى رعايت سياستهاى سازمانى، كزارش مسائل اخلاقى به ردههاى بالاى سازمان

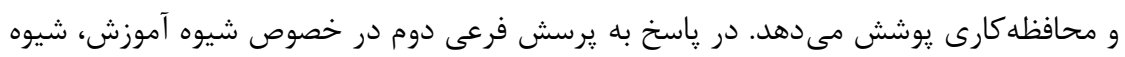

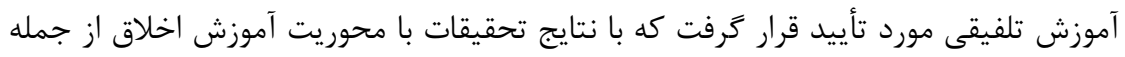

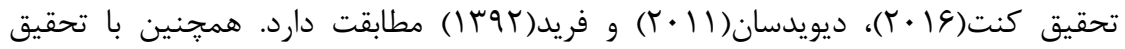


حسينى و بابائى(91 (I) در خصوص ضرورت شكل گيرى تفكر انتقادى دانشجويان در موضوعات

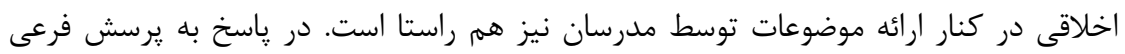

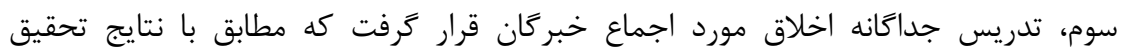

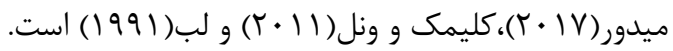
تاكنون كوششهاى بسيارى در كشورمان به منظور نشان دادن اهميت آموزش اخلاق در

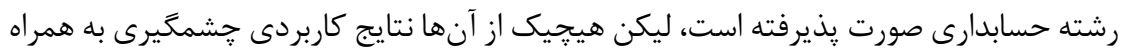

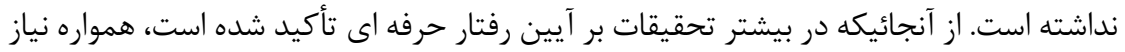

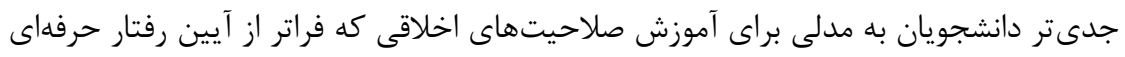

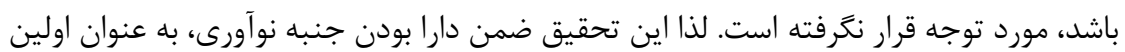
مدل آموزش صلاحيتهاى اخلاقى در شته حسابدارى در ايران مىباشد. لذا، با بروزرسانى رشته

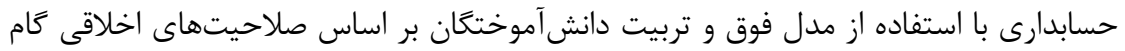

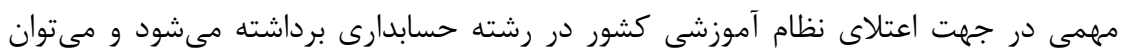
اميدوار بود كه موجبات اعتماد بيشتر افراد جامعه به حرفه حسابدارى و نيز رفاه اجتماعى فراهم

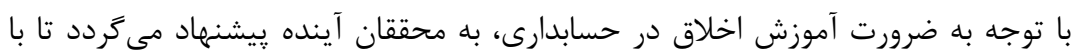

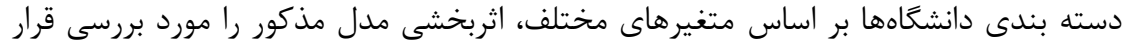

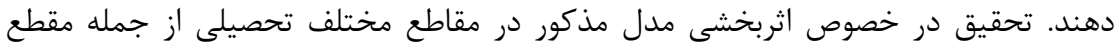

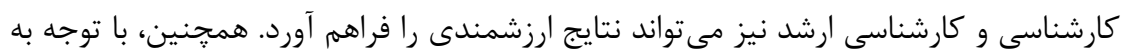

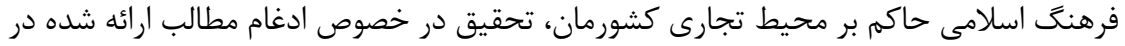

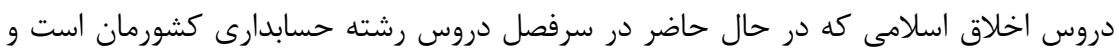

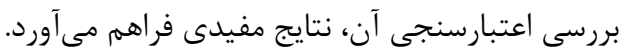

V - Vقدير، تشكر و ملاحظات اخلاقى بدينوسيله از كليه عزيزانى كه با تكميل يرسشنامه تحقيق ما را دادر انجام اين تحقيق يارى نمودند كمال تشكر و قدردانى را داريم.

$$
\text { 1 - بِيوست: }
$$

يرسشنامه بِيشرو در راستاى جمعآورى بخشى از اطلاعات مورد نياز يزوهش با عنوان" مدل سه

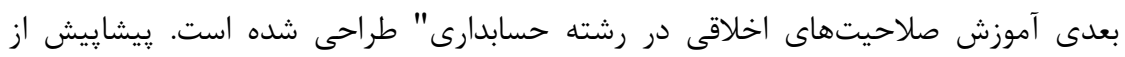


مساعدت و حوصله شما و نيز وقت گرانبهايى كه در اختيارمان قرار مىدهيد سياسگزاريم. بديهى است كه همكارى شما در كمك به ييشبرد اهداف يثوهش بسيار مؤثر خواهد بود.

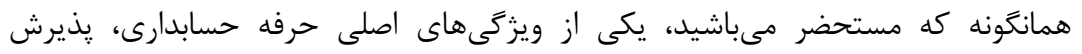

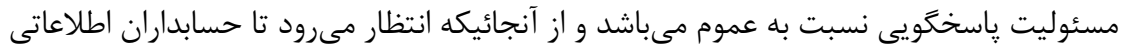
را در اختيار استفادهكنندكان قرار دهند كه توان تصميمَيرى و قضاوت ايشان را افزايش دهد،

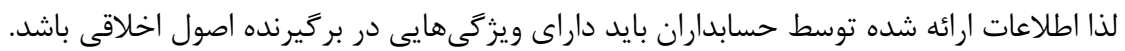

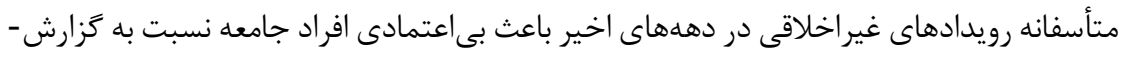
هاى مالى و صحت آنها شدهاست. بنابراين، حرفه حسابدارى نيازمند توجه جدى تر بر به اخلاق

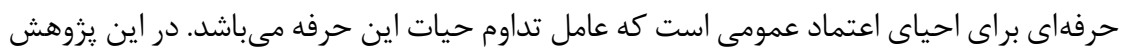
سعى شده است صلاحيتهاى اخلاقى مورد نياز دانشآموختخان حسابدارى كه وارد بازاركار مىشوند، روش تدريس و دسته درسى تدريس صلاحيتهاى مذكور از ديدگاه استادان و شاغلان

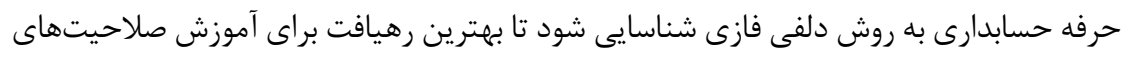

$$
\text { اخلاقى در رشته حسابدارى انتخاب شود. }
$$

سؤال هاى عمومى به صورت انتخابى جندگزينهاى و نوشتارى است و سؤالهاى تخصصى بـ

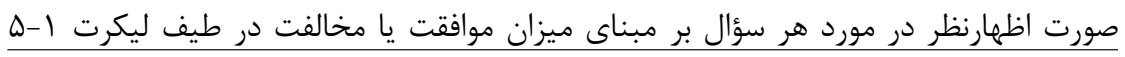

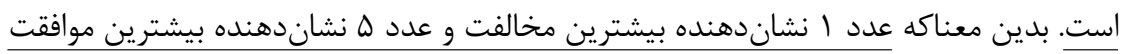
است. لازم به ذكر است در اين مرحله صرفاً شناسايى صلاحيتهاى اخلاقى مورد نياز براى اتخاذ

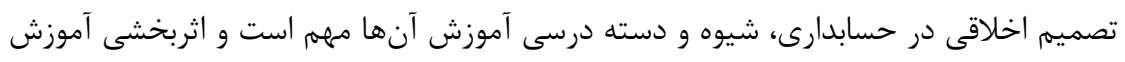
صلاحيتهاى فوق در مرحله بعد مشخص خواهد شد. جنانجه علاقهمند به نوشتن توضيحات

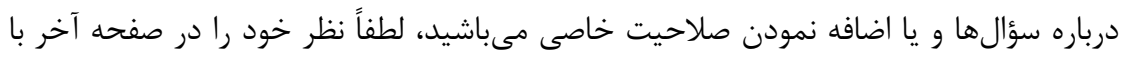

$$
\text { ذكر شماره سؤال بنويسيد. }
$$

$$
\text { الف- سؤال هاى عمومى سمي لرهو }
$$

$$
\begin{aligned}
& \square \text { r. }
\end{aligned}
$$

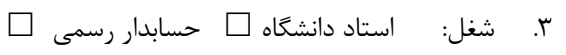

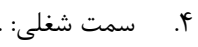

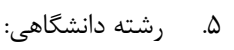

$$
\begin{aligned}
& \text { حسابدارى } \quad \square
\end{aligned}
$$

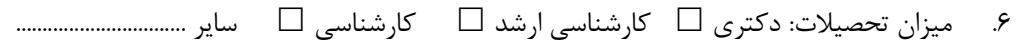

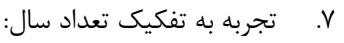

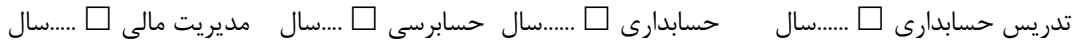

$$
\begin{aligned}
& \text { ساير................. }
\end{aligned}
$$


دكترباباجانى و همكاران، مدل سه بعدى آموزش صلاحيتحهاى اخلاقى در رشته حسابدارى

ب- سؤال هاى تخصصى () به نظر شما در حوزه شناختى، آيا صلاحيتهاى اخلاقى مشروحه زير موجب ارتقاى تصميمهاى اخلاقى حسابداران مي شوند ؟

\begin{tabular}{|c|c|c|c|c|c|}
\hline \multicolumn{5}{|c|}{ 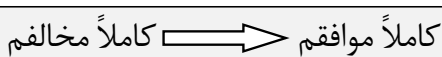 } & \multirow[b]{2}{*}{ تعيين و تشخيص موضوعات اخلاقى } \\
\hline$\square ।$ & $\square r$ & $\square$ & $\square r$ & $\square \Delta$ & \\
\hline$\square 1$ & $\square r$ & $\square$ & $\square r$ & $\square \Delta$ & شفافسازى اخلاقى معضلات موجود در محيط كار \\
\hline$\square ।$ & $\square r$ & $\square$ & $\square r$ & $\square \Delta$ & زَزارش مسائل اخلاقى به رده هاى بالاى سازمان \\
\hline$\square$ । & $\square r$ & س & $\square r$ & $\square \Delta$ & رقررات \\
\hline$\square 1$ & $\square r$ & $\square$ & $\square r$ & $\square \Delta$ & رعايت همهجانبه استانداردهاى حرفه \\
\hline$\square ।$ & $\square r$ & $\square$ & $\square r$ & $\square \Delta$ & ازمانى \\
\hline
\end{tabular}

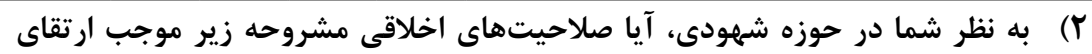

\begin{tabular}{|c|c|c|c|c|c|}
\hline \multicolumn{6}{|r|}{ تصميمهاى اخلاقى حسابداران مىشوند؟ } \\
\hline$\square 1$ & $\square r$ & س & $\square r$ & $\square \Delta$ & صداقت و درستكارى \\
\hline \multicolumn{6}{|c|}{ 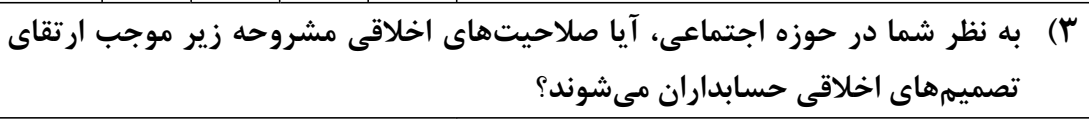 } \\
\hline \multicolumn{6}{|c|}{ 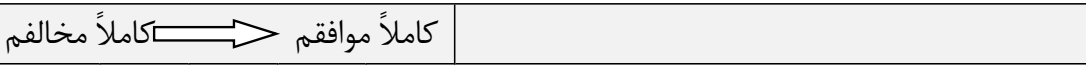 } \\
\hline$\square 1$ & $\square r$ & $\square r$ & $\square r$ & $\square \Delta$ & بىطرفى و استقلال \\
\hline$\square ।$ & $\square r$ & r & $\square r$ & $\square \Delta$ & حفظ حقوق ذينفعان \\
\hline$\square 1$ & $\square r$ & $\square r$ & $\square r$ & $\square \Delta$ & حفظ شهرت حرفه \\
\hline$\square ।$ & $\square r$ & r & $\square r$ & $\square \Delta$ & سهيم بودن در مسئوليتهاى اجتماعى و زيست \\
\hline \multicolumn{6}{|c|}{ 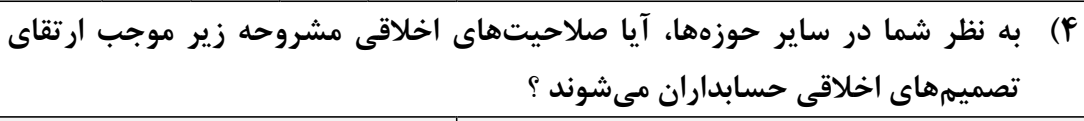 } \\
\hline \multicolumn{5}{|c|}{ 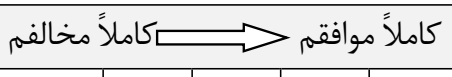 } & صلاحيت هاى اخلاقى \\
\hline$\square ।$ & $\square r$ & r & $\square r$ & $\square \Delta$ & انجام كامل و دقيق امور \\
\hline$\square 1$ & $\square r$ & 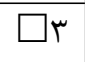 & $\square r$ & $\square \Delta$ & تأكيد بر آموزش مستمر \\
\hline$\square 1$ & $\square r$ & r & $\square r$ & $\square \Delta$ & محافظه كارى \\
\hline
\end{tabular}


دو فصلنامه حسابدارى ارزشى و رفتارى، سال ينجم، شماره دهم، پِاييز و زمستان وجسا

\begin{tabular}{|c|c|c|c|c|c|}
\hline & & & & & ساير صلاحيتهاى اخلاقى يِشنهادى: \\
\hline & & & 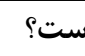 & 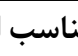 & ه) كدام شيوه براى آموزش صلاحيتهاى اخلاقى م \\
\hline 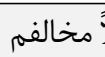 & ـ كامل & $\Rightarrow$ & 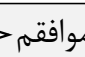 & كاملاً & شيوه آموزش صلاحيتهاى اخلاقى \\
\hline$\square 1$ & $\square r$ & $\square r$ & $\square f$ & $\square \Delta$ & 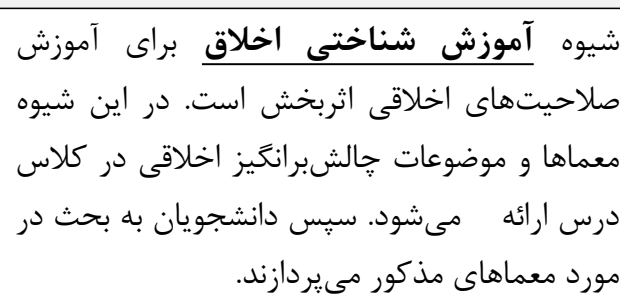 \\
\hline$\square 1$ & $\square r$ & $\square r$ & $\square r$ & $\square \Delta$ & 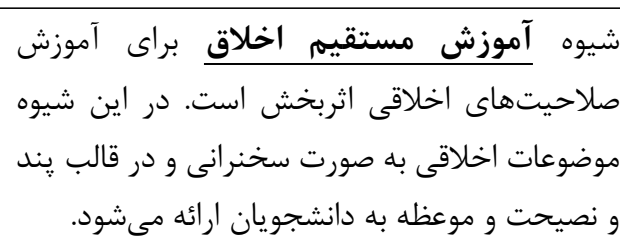 \\
\hline$\square 1$ & $\square r$ & $\square$ & $\square r$ & $\square \Delta$ & 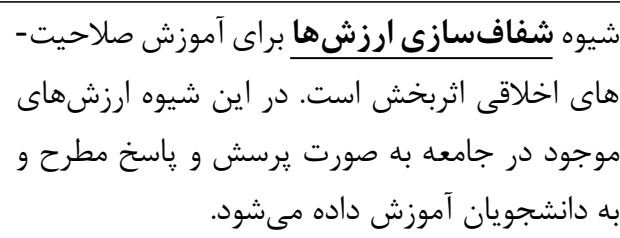 \\
\hline$\square 1$ & $\square r$ & $\square r$ & $\square r$ & $\square \Delta$ & 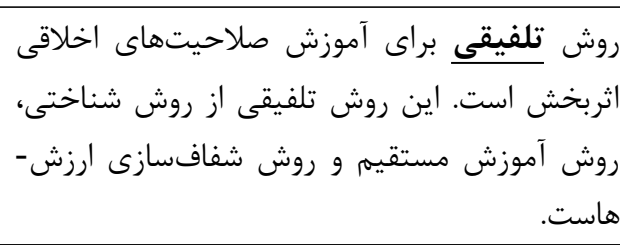 \\
\hline 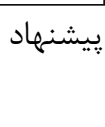 & & & & & مى دهيد: طور كلى كدام روش از روشهاى فوق را براى \\
\hline 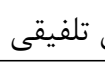 & & & زى ارزز & we & 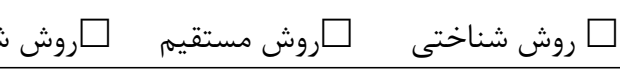 \\
\hline 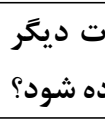 & كار & 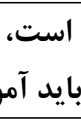 & 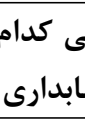 & 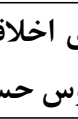 & 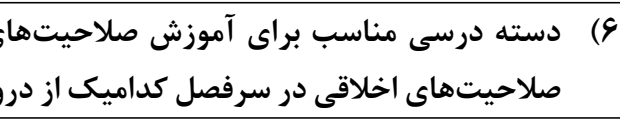 \\
\hline 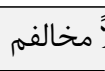 & كامل & $\Rightarrow$ & 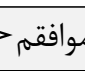 & كاملاً & دسته درسى آموزش صلاحيتهاى اخلاق \\
\hline$\square 1$ & $\square r$ & $\square$ r & $\square r$ & $\square ه$ & تدريس جدارى اثربخش استه صلاحيتهاى اخلاقى در رشته \\
\hline
\end{tabular}




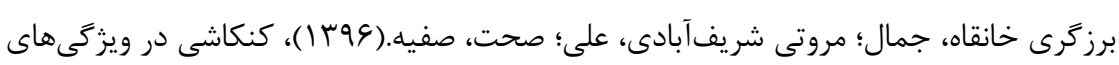

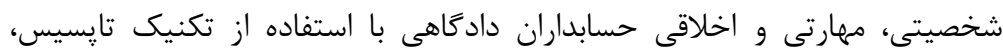

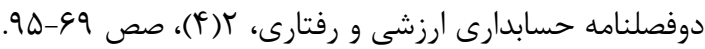

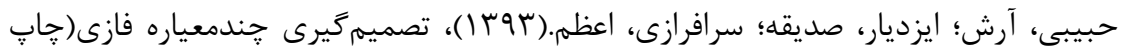

$$
\begin{aligned}
& \text { اول)، انتشارات سيماى دانش. } \\
& \text { حسينى، سيدعلى و بابائى، فاطمه.(1) (1)، ضرورت آموزش اخلاق و ارزشهاى اسلامى در برنامه } \\
& \text { درسى حسابدارى در دانشخاهها، فصلنامه يزوهش حسابدارى و حسابرسى، } 9(\text { (1)، صصى لو } \\
& ||\langle\Delta-Y| \\
& \text { رضائى منش، بهروز و آرزومند، وحيد.(Yq (1)، تأثير فرهنگ سازمانى و اخلاق حرفهاى بر كيفيت }
\end{aligned}
$$

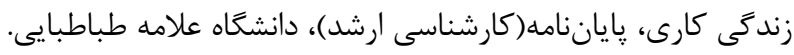

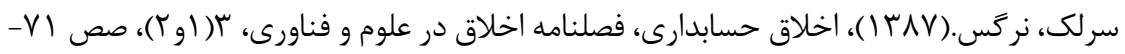

$$
\begin{aligned}
& \text { AT }
\end{aligned}
$$

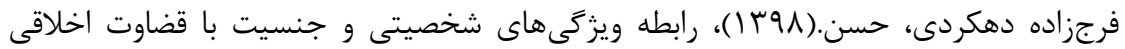

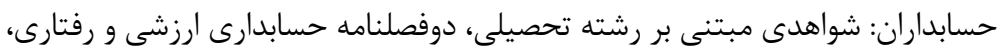

$$
\begin{aligned}
& r \cdot 1-|1| \text { r. } \\
& \text { فريد، ابوالفضل.(rوץ|)، بررسى اثربخشى روشهاى آموزش مستقيم، آموزش شناختى اخلاق، }
\end{aligned}
$$

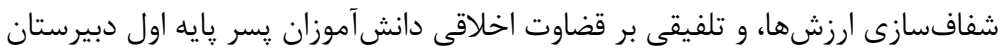

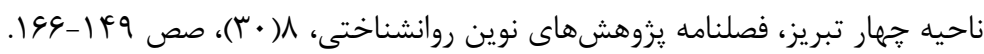

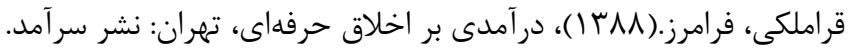

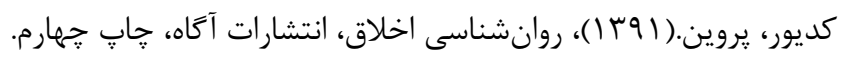

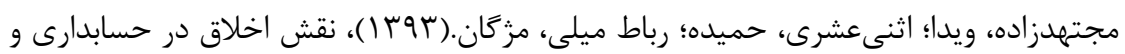

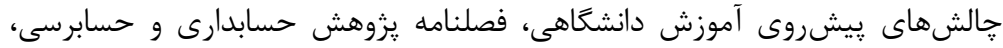

$$
\begin{aligned}
& \text { IVq-IDV } \\
& \text { نمازى، محمد و ابراهيمى، فهيمه.(9 ب ())، بررسى تأثير سازههاى فردى و اجتماعى بر شدت } \\
& \text { اخلاقى ادراك شده توسط حسابداران، دوفصلنامه حسابدارى ارزشى و رفتارى، ؟(أ)، } \\
& \text { صص MV }
\end{aligned}
$$

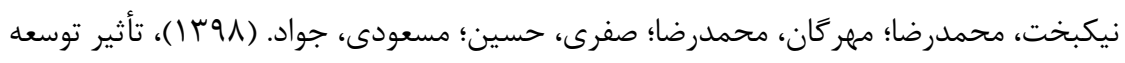

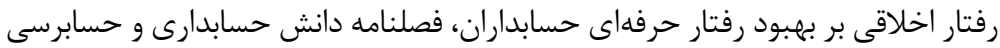

$$
\begin{aligned}
& \text { مديريت، }
\end{aligned}
$$




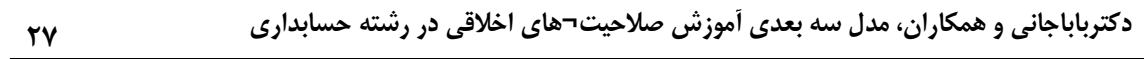

Bakar, M.A., M.S. Maisarah, and A.M. Ainun. 2003. Ethics and the Accounting Profession in Malaysia. National Accounting Research Journal.1(1):105-122.

Candidate Bulletin. 2016. Roadmap to CPA Success. Available at: http://bit.1y/2e0dGYM.(Last accessed March 26, 2020).

Davidson, R.A. 2011. Ethics! Teaching Ethics to Accounting Students. Annual summit on Business and Entrepreneurial studies Proceeding. 2(1): 224-234.

Dunn, P., and B. Sainty. 2020. Professionalism in Accounting: A Fivefactor Model of Ethical Decision-making. Social Responsibility Journal. 16(2): 255-269.

Kent, C. 2016. A Qualitative Study of Problem-based Learning in Accounting Education and its Effect on Career Preparation. Ph.D. Thesis. University of Phoenix.

Khanifah, Kh., J. Isgiyarta, I. Lestari, and U. Udin. 2019. The Effect of Gender, Locus of Control, Love of Money, and Economic Status on Students' Ethical Perception. International Journal of Higher Education. 8(5): 168-175.

Klimek, J., and K. Wenell. 2011. Ethics in Accounting: An Indispensable Course? Academy of Educational Leadership Journal. 15(4):107-118.

Lawson, R.A., E.J. Blocher, P.C. Brewer, G. Cokins, J.E. Sorensen, D.E. Stout, and M.J.F. Wouters. 2014. Focusing Accounting Curricula on Students' Long-run Careers: Recommendations for an Integrated Competency-based Framework for Accounting Education. Issues in Accounting Education, 29(2): 295-317.

Loeb, S.E. 1991. The Evaluation of "Outcomes" of Accounting Ethics Education. Journal of Business Ethics. 10(2): 77-84.

Meador, G.P. 2017. Ethical Decision-making Accounting Competencies: Practitioners' Perspectives. Ph.D. Thesis. University of Southern Mississippi.

Miller, F., and T.J. Shawver. 2018, An Exploration of the State of Ethics in UK Accounting Education. Journal of Business Ethics. 153(4): 1109-1120.

Neesham, C., and M.I. Azim. 2017, Building Ethical Capability for Accounting Professionals. A Needs Analysis Study. Swinburne 
دو فصلنامه حسابدارى ارزشى و رفتارى، سال ينجم، شماره دهم، پِاييز و زمستان وجسا

University of Technology under Global Research Perspectives Program of CPA Australia: 1-66.

Rest, J.R.1986. Moral Development: Advances in Research and Theory. New York: Praeger.

The Pathway Commission. 2012. Charting a National Strategy for the Next GenerationofAccountants. Available at: http://commons.aaahq.org/files/0b14318188/Pathways_Commission Final_Report_Complete.pdf(Last accessed March 26, 2020).

The Pathways Commission. 2015. In Pursuit of Accounting's Curricula of the Future. American Accounting Association. Available at: http://commons.aaahq.org/posts/c0a7037eea (Last accessed March 26, 2020).

The Chartered Professional Accountant Competency Map. 2018. Understanding the Competencies a Candidate Must Demonstrate to Become a CPA. Chartered Professional Accountants Canada. Available at: https://www.cpacanada.ca/en/become-a-cpa/pathways-to-becominga-cpa/national-education-resources/the-cpa-competency-map (Last accessed March 26, 2020).

West, A., and Sh., Buckby. 2020. Ethics Education in the Qualification of Professional Accountants: Insights from Australia and New Zealand. Journal of Business Ethics. 164: 61-80. 